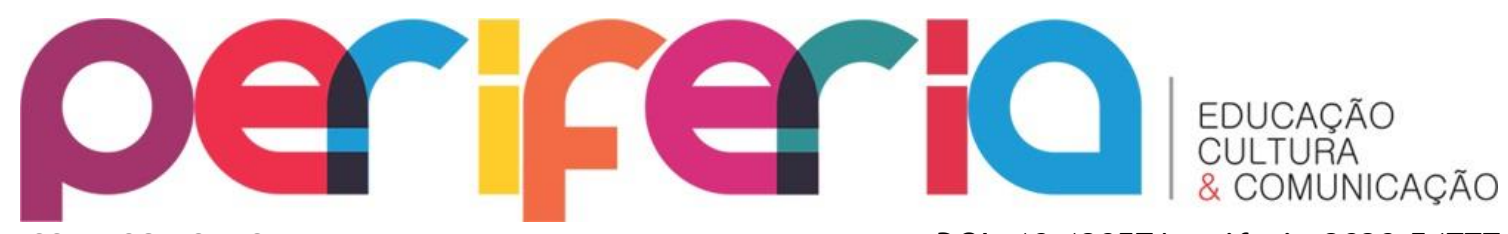

\title{
JOÃOZINHO DA GOMÉIA: REI DO CANDOMBLÉ E REI DA MÍDIA
}

\author{
Ricardo Oliveira de Freitas ${ }^{1}$
}

\section{Resumo}

O texto analisa a importância do uso de recursos de mídia e de expressões em arte pelo Rei do Candomblé para a reconfiguração do campo religioso afrobrasileiro e para a construção de um imaginário social sobre o candomblé. Afirma que as aparições em mídia, mais que permitirem a Joãozinho do Goméia ocupar um lugar de destaque no mercado da oferta de serviços mágico-religiosos, contribuíram para desmistificar a imagem do candomblé como relacionado à selvageria, à barbárie, ao exercício de falsa medicina, à obscenidade, à anormalidade mental, à delinquência e a um sem número de representações negativas que recaíam sobre essas religiões. Reconhece que Joãozinho, através da efetiva exploração das formas plásticas e da riqueza estética das religiões afro-brasileiras, contribuiu para positivar a imagem dessas religiões junto à esfera pública política, à esfera de visibilidade midiática e, por extensão, à opinião pública, nos termos de Habermas (1984), além de criar uma arena paralela, alternativa e radical, nos termos de Fraser (1985) e Downing (2002), respectivamente. Ao extrapolar os limites do universo religioso afro-brasileiro e promover, através da recorrente presença em mídia, o diálogo entre a sociedade brasileira mais ampla e o universo religioso afro-brasileiro, Joãozinho deu forma não somente à uma nova cultura religiosa afro-brasileira, num tipo de luta pela significação, através da positivação midiática e representacional da Goméia, do candomblé angola ou das religiões afro-brasileiras, mas à importante e consolidado projeto de valorização da cultura negra no Brasil e nas Américas.

Palavras-chave: Joãozinho da Goméia; Goméia; Religiões Afro-Brasileiras; Candomblé e Mídia.

\footnotetext{
${ }^{1}$ Possui Graduação em Artes pela UFRJ (1992), Mestrado em Comunicação e Cultura pela UFRJ (1995) e Doutorado em Comunicação e Cultura pela UFRJ (2002). Realizou Pós-Doutorado em Estudos Culturais pelo Programa Avançado em Cultura Contemporânea da UFRJ com bolsa CNPq. É Professor Titular da UNEB/Campus I, Professor Permanente do Programa de Pós-Graduação em Estudos das Linguagens PPGEL/UNEB e Professor Permanente do Programa de Pós-Graduação em Letras, Linguagens e Representações - PPGL/UESC. Coordena o Grupo de Pesquisa e Estudos em Midiativismo e Midialternativas - GUPEMA. ORCID iD: https://orcid.org/0000-0002-7528-4488. E-mail: ricofrei@gmail.com
} 


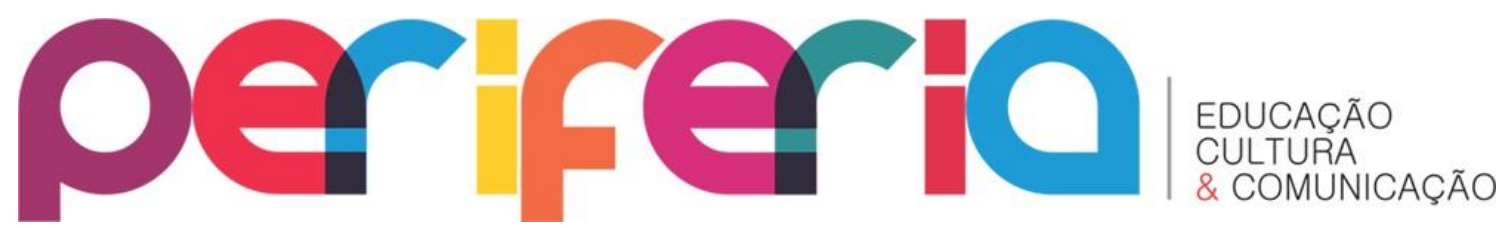

ISSN:1984-9540

DOI: $10.12957 /$ periferia.2020.54777

JOÃOZINHO DA GOMÉIA: KING OF CANDOMBLÉ AND KING OF

MEDIA

\section{Abstract}

This paper presents an analysis of the importance of the use of media resources and arts expressions by the King of Candomble to reconfigure the Afro-Brazilian religious field and to build a new social imaginary about the candomblé. It claims that the media participation and apparitions, more than allowing Joãozinho da Goméia to occupy a prominent place in the market of magical-religious services, contributed to demystify candomblés image as related to savagery, barbarism, false medicine, obscenity, mental abnormality, delinquency and countless negative representations built about these religions. It recognizes that Joãozinho, through effective exploration of plastic forms and aesthetic richness of Afro-Brazilian religions, contributed to posit the image of these religions in the political public sphere, the sphere of media visibility and public opinion, according to Habermas (1984), in addition to creating a parallel, alternative and radical arena, according to Fraser (1985) and Downing (2002), respectively. By extrapolating the limits of the Afro-Brazilian religious universe and promoting, through his recurrent media presence, the dialogue between the Brazilian society and the Afro-Brazilian religious universe, Joãozinho shaped not only a new Afro-Brazilian religious culture, in a type of struggle for meaning, through the media and the positive representations of the Goméia, the Angola candomble or the Afro-Brazilian religions, but, also, an important and a consolidated project for the valorization of Black culture in Brazil and in the Americas.

Keywords: Joãozinho da Goméia; Goméia; Afro-Brazilian Religions; Candomblé and Media.

\section{JOÃOZINHO DA GOMÉIA: REY DEL CANDOMBLÉ Y REY DE LOS MEDIOS}

\section{Resumen}

El texto presenta un análisis de la importancia del uso de los recursos mediáticos y de las expresiones en Artes por parte del Rey del Candomblé para reconfigurar el campo religioso afrobrasileño y para la construcción de un imaginario social sobre el candomblé. Afirma que las apariciones y la participación en los vehículos de comunicación, más que permitieren que Joãozinho da Goméia ocupe un lugar destacado en el mercado de la oferta de servicios mágico-religiosos, contribuyeron a desmitificar la imagen del candomblé en relación con el salvajismo, la barbarie, el ejercicio de la falsa medicina, la obscenidad, la anormalidad mental, la delincuencia e innumerables representaciones negativas que recayeron sobre estas religiones. Reconoce que Joãozinho, a través de la exploración efectiva de las formas plásticas y la riqueza estética de las religiones afrobrasileñas, 


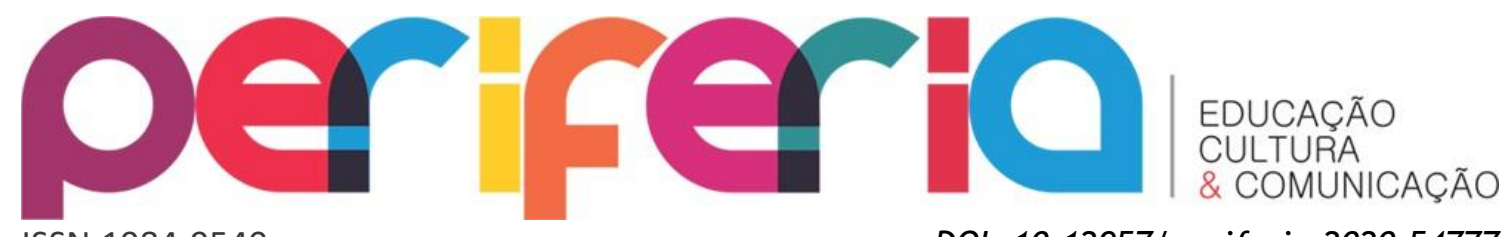

ISSN:1984-9540

DOI: $10.12957 /$ periferia.2020.54777 contribuyó a posicionar la imagen de estas religiones en la esfera pública política, la esfera de la visibilidad mediática y, por extensión, la opinión pública, según Habermas (1984), además de crear un escenario paralelo, alternativo y radical, según Fraser (1985) y Downing (2002), respectivamente. Al extrapolar los límites del universo religioso afrobrasileño y promover, a través de su presencia recurrente en los medios, el diálogo entre la sociedad brasileña en general y el universo religioso afrobrasileño, Joãozinho moldeó no solo una nueva cultura religiosa afrobrasileña, en un tipo de lucha por el sentido, a través de la positivización mediática y representacional de la Goméia, del candomblé angola y de las religiones afrobrasileñas, pero, también, a un importante y un consolidado proyecto de valorización de la cultura negra en Brasil y en las Américas.

Palabras clave: Joãozinho da Goméia; Goméia; Religiones Afrobrasileñas; Candomblé y Media. 


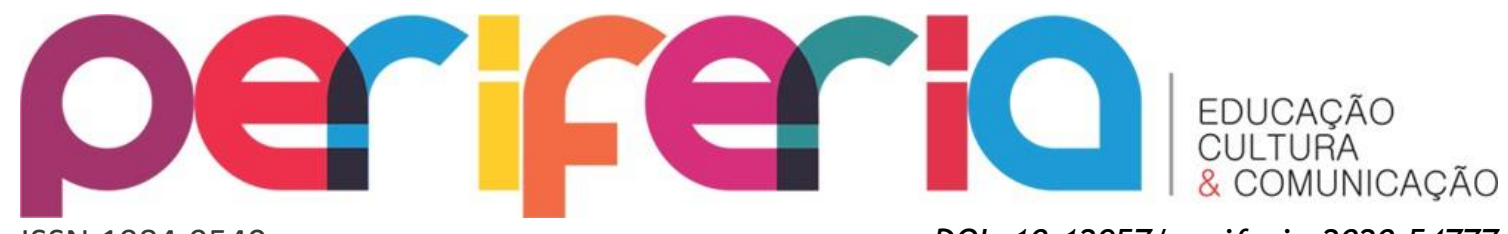

Se a Bahia é a sementeira dos cultos afro-brasileiros, a Baixada Fluminense é, hoje em dia, o seu mais fértil terreno de cultivo, que a migração religiosa começada na segunda metade do século passado, acompanhando a migração de trabalhadores baianos para a região do Rio de Janeiro, não cessou, embora se possa dividi-la em duas fases de maior intensidade. Aquela, primeira, canalizada principalmente para as áreas mais pobres do centro da cidade ("conheci as casas das ruas de São Diogo, Barão de São Félix, Hospício, Núncio e da América, onde se realizam os candomblés e vivem os paisde-santo", escrevia o jornalista João do Rio em 1905, em seu escandalizado francesismo) e outra canalizada para a Baixada, na medida em que essa área periférica - municípios de Caxias, Nilópolis, São João de Meriti e Nova Iguaçu - integram-se à cidade para formar o Grande Rio, nos últimos trinta anos. As afinidades sócio-culturais dos dois centros urbanos, núcleos originais de concentração negra, e o elo religioso já estabelecido antes, principalmente através das famosas tias, presentes também na formação da música urbana carioca, justificam a nova corrente migratória religiosa. [...] Vieram pais e mães-de-santo já de nomeada na Bahia, como Ciriaco do Tumba Juçara, Otávio da Ilha Amarela, Idalice, Zezé (estes citados por Edson Carneiro em seu Candomblé da Bahia), Miguel Arcanjo (Miguel Grosso), Senhorazinha, Ebami Davina, Antonio Fumutim do Bogum, João Lessengue do Bate-Folha, Rufino do Beiru, (lembrados por Lázaro de Oliveira) e muitos e muitos outros, perpetuados numa descendência de milhares e milhares de filhos-de-santo, nos cantos, nos ritos e nos preceitos das nações Keto, Gege, Igexá, Angola, Congo, Nagô, Vodum, Muxe Congo. Pode-se dizer que a Bahia e a Baixada formam hoje uma só unidade religiosa, embora sob a inegável ascendência baiana (Juarez Barroso, texto extraído da contracapa do LP Cânticos de Candomblé, do babalorixá Lázaro Ourualê, produzido por Candeia, 1979).

\section{Bandagira Tata}

No dia 19 de março de 1971, a imprensa brasileira noticiou, através da veiculação nos mais diversos meios e veículos de comunicação (rádio, TV, jornal e revista), a comoção popular que se abateu sobre as ruas de Caxias, município localizado na região metropolitana do Rio de Janeiro, por conta do falecimento do babalorixá Joãozinho da Goméia. Desde Caxias, a notícia repercutiu pelo Brasil, tornando conhecidos tanto o relato da morte, 


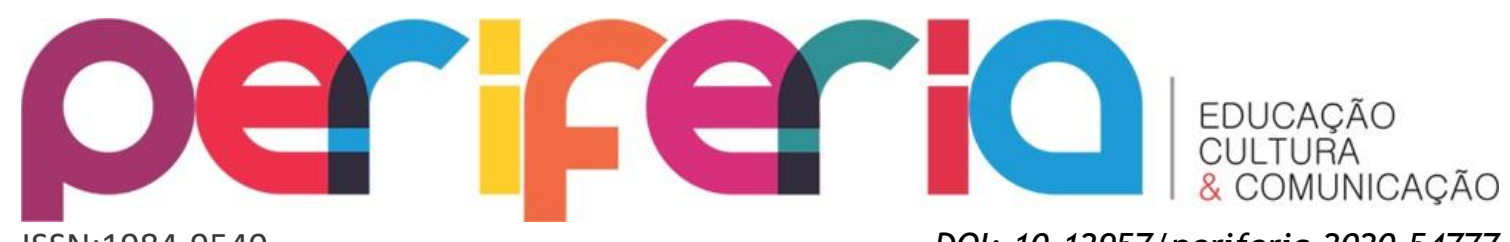

ISSN:1984-9540

DOI: $10.12957 /$ periferia.2020.54777 propriamente, como o nome do município. Ouso dizer que o enterro de João inscreveu o nome de Caxias no imaginário social brasileiro, marcando o município, assim como Codó, no Maranhão, e Salvador, na Bahia, na seleta lista de municípios citados como "a terra da macumba boa", com tudo o que isso pode ter de clichê e estereótipo. Também arrisco dizer que o enterro de João foi, certamente, um dos mais concorridos funerais do Rio de Janeiro, quiçá do Brasil. E a motivação para que tal fato acontecesse não se deve apenas à sua importante participação no universo religioso afro-brasileiro, mas, sobretudo, ao fato de Joãozinho ter sido, além de babalorixá, uma personalidade, no sentido mais midiático do termo ${ }^{3}$.

João Alves Torres Filho, João da Goméia, Joãozinho da Goméia, João da Pedra Preta ou Tata Londirá, nasceu em 1914, em Inhambupe, no sertão da Bahia. Na adolescência, muda-se para Salvador, onde será iniciado na religião dos orixás e, anos mais tarde, constituirá sua própria casa de santo, um terreiro situado numa localidade de nome Goméa, no bairro de São Caetano, de onde provém a alcunha Joãozinho da Goméia e Terreiro da Goméia. Tempos depois, muda-se para o Rio de Janeiro, onde consolida sua imagem, senão como o maior porta-voz das religiões afro-brasileiras, ao menos como a maior liderança masculina do universo religioso afro-brasileiro.

O contato de João com o mundo da ciência, das artes, da comunicação e da política não teve início no Rio de Janeiro, propriamente. João, ainda na Bahia, dialogará com os meios de comunicação e com intelectuais (do campo das artes e da academia). 0 mesmo vale para suas articulações com políticos. Mas é sobretudo a partir da sua mudança para o Rio de Janeiro, capital da República, em 1946, que João fará crescer sua fama e reconhecimento junto

\footnotetext{
${ }^{2}$ Devo confessar que, durante a escrita desse texto, absolutamente todas as vezes em que que escrevi João ou Joãozinho, o "Seu", de "Seu João", surgia no teclado sem que eu me desse conta. Optei por não utilizar o substantivo, pois acreditei que seria cansativo para o leitor ler tantas vezes "Seu" no texto. Mas, a falta do "Seu" não retira meu respeito à pessoa de Seu João e à sua família de santo.

${ }^{3}$ Há farto material na mídia impressa sobre a morte de João. A revista Manchete, por exemplo, publicou matéria com quatro páginas inteiras intitulada "Funeral para um Rei Negro: o candomblé ficará de luto durante um ano, devido à morte de Joãozinho da Goméia, o mais antigo babalorixá brasileiro". Edição 989, 3 abr. 1971. Ver foto abaixo.
} 


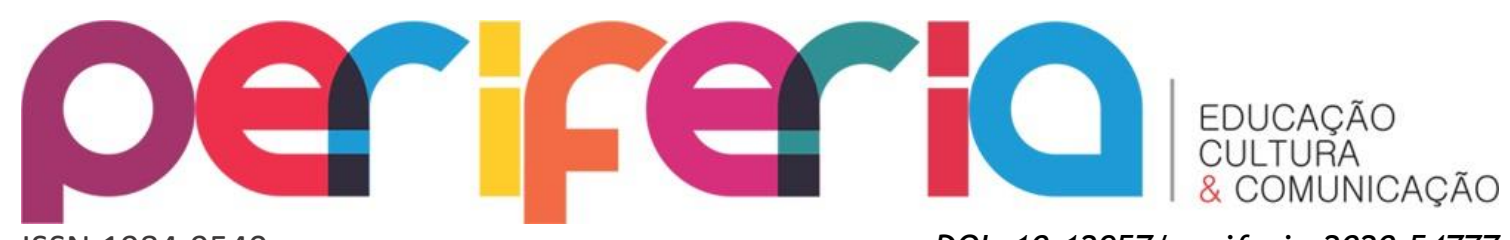

ISSN:1984-9540

DOI: $10.12957 /$ periferia.2020.54777 à opinião pública, tornando-se não somente o Rei do Candomblé, mas também um difusor e, por isso, embaixador da cultura afro-brasileira para o mundo.

Polo econômico do país e epicentro da produção da indústria cultural brasileira, já contando com uma sociedade urbana, industrial e de consumo consolidada, é no Rio de Janeiro, mais precisamente no bairro de Copacabana, em Duque de Caxias, que, a partir de 1948, João fixará seu novo terreiro, quando se projetará para o mundo através da exaltação à cultura afro-brasileira que, aqui, não diz respeito tão somente à cultura religiosa de matriz africana. Afinal, João dialogou com um sem-número de expressões em cultura e artes negro-brasileiras, quando, além de babalorixá, foi ator, radialista, produtor cultural, folião, dançarino, cantor e vedete. Por isso, pode-se afirmar que João foi importante não somente pelo fato de tornar públicas as religiões afro-brasileiras ${ }^{4}$ de modo geral mas, sobretudo, pelo fato de ter sido um porta-voz da causa negra, revelando, através das suas aparições em jornais, revistas, cinema, TV, teatro, rádio, indústria fonográfica e livros, a força da expressividade plástica e das poéticas estéticas do povo negro, assim como a importante participação e contribuição da rica e sofisticada cultura afro-brasileira na constituição do processo civilizatório brasileiro.

Apesar de João ter sido e ser, ainda hoje, o maior babalorixá do Brasil, nosso interesse reside justamente no fato de que não foi seu conhecimento acerca das "coisas de santo" nem sua atuação no universo religioso, propriamente, o que the deu fama; mas, sobretudo, suas muitas articulações e negociações com políticos e intelectuais (do mundo das artes e da ciência) da época, assim como sua percepção sobre a importância de ocupar a mídia,

\footnotetext{
${ }^{4}$ Devo ressaltar que quando me refiro às causas de João por representatividade, estou assumindo que ele foi importante para a totalidade do que trato por religiões afro-brasileiras - e não somente para os cultos de tradição baiana, o candomblé. Por isso, religiões afro-brasileiras, aqui, referem-se tanto ao candomblé como ao tambor de mina, à jurema, ao xangô, à pajelança, à umbanda, ao babaçuê, ao batuque, ao catimbó, ao jarê, ao terecô e a toda sorte de expressões religiosas de matriz africana e ameríndias praticadas pelo Brasil afora. Devo, ainda, dizer que reconheço as especificidades de cada uma dessas expressões religiosas, além de saber da importância de João da Goméia para o candomblé, para o candomblé angola.
}

Periferia, v. 12, n. 3, p. 94-128, set./dez. 2020 


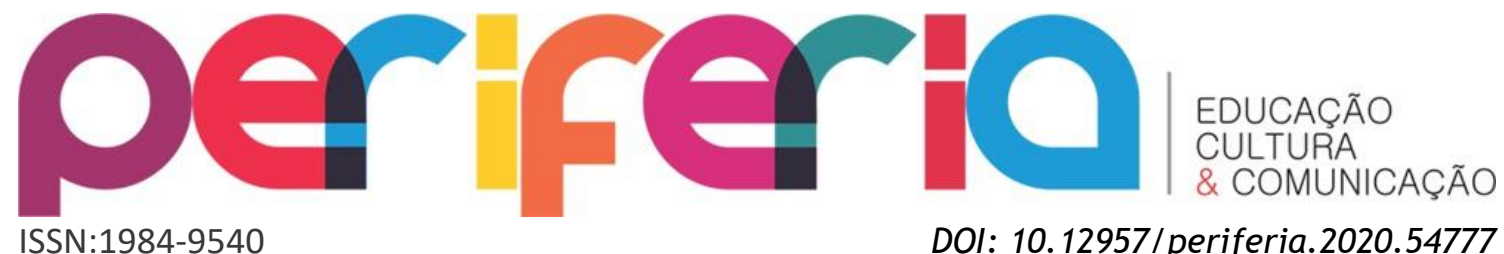

mesmo que para isso tivesse que produzir escândalos ${ }^{5}$, o que the confere o título de Rei da Mídia. A concepção de mídia aqui utilizada não é somente a da sua tradução mais clássica, como conjunto de meios e veículos de comunicação social de massas mas, sobretudo, a definição proposta por John Downing (2002), ao instituir o conceito de mídia radical alternativa como caracterizada por diversos tipos de mídias não convencionais, que perpassa uma amplitude de suportes, veículos, expressões, sensibilidades e experiências estéticas, que vão desde o jornal impresso até a dança afro e a indumentária.

Nesse sentido, afirmo que João foi, em seu tempo, um agente da mídia radical alternativa, um criador de conteúdo e influenciador midiático analógico (muito próximo do que concebemos hoje como sendo um influenciador digital). Ou seja, afirmo que João foi um potencial formador de opinião, que criou contranarrativas acerca do candomblé e, por extensão, da cultura afro-brasileira e do seu povo, que, ao positivar a cultura negra, através da exaltação das suas estéticas e plasticidades, contribuiu sobremaneira para a criação de uma contrainformação e para a produção de um contradiscurso sobre ser negro no Brasil racista, o que extrapola o aspecto meramente religioso.

\footnotetext{
${ }^{5}$ É famoso o imbróglio envolvendo João e o pai de santo Benedito Espírito Mau acerca da posse de uma filha de santo, o que rendeu, por quase cinco meses do ano de 1952, expressivas matérias nos jornais cariocas (cf. Gama, 2012).
} 

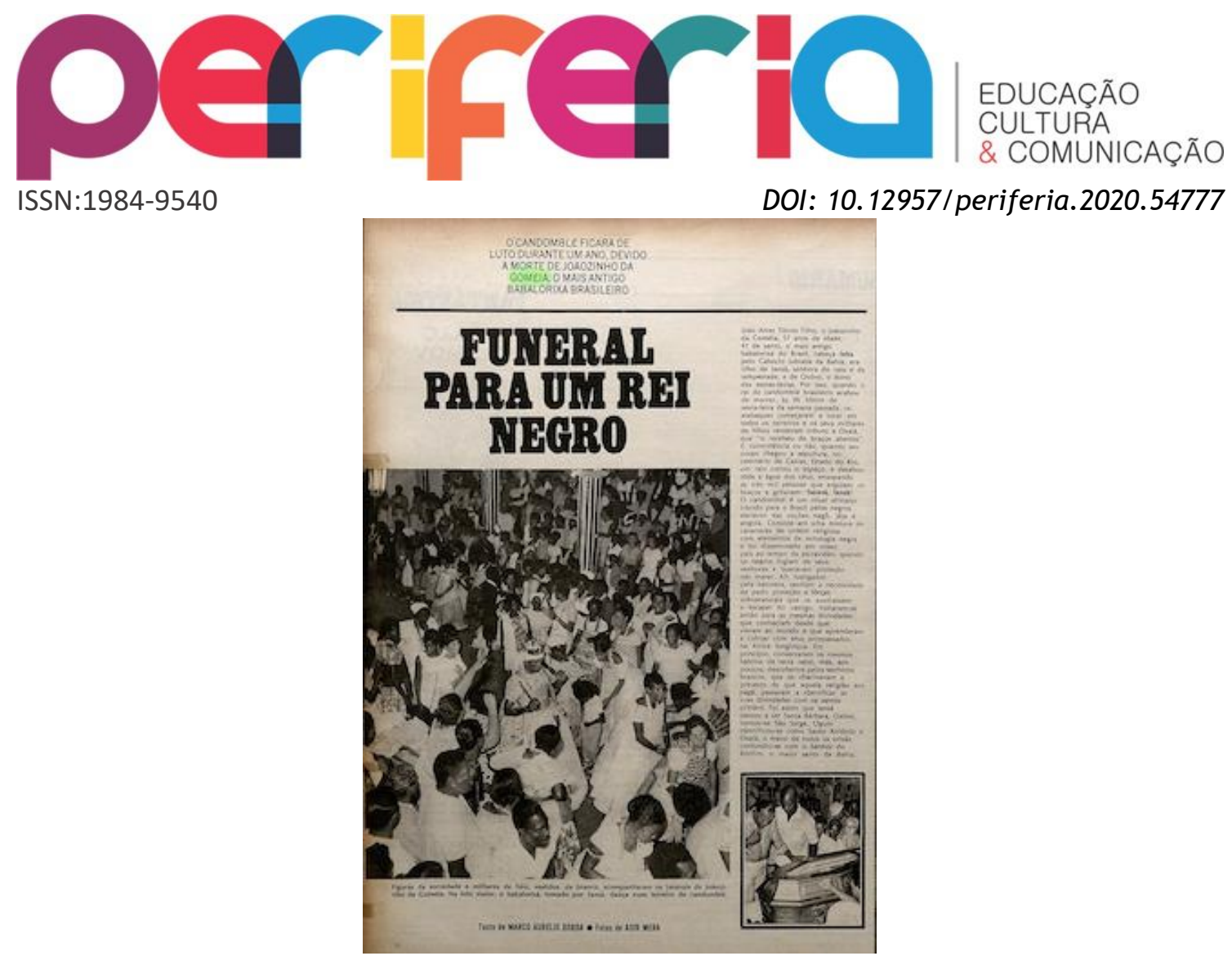

\section{Malembe}

Manchete, 3 abr. 1971.

João Alves Torres nasceu em 1914, em Inhambupe. Ainda jovem, se muda para a capital, Salvador, onde conhece uma mulher idosa, a quem passou a chamar "madrinha”. Por conta de uma dor de cabeça incessante, sua madrinha, depois de recorrer aos médicos, leva João ao terreiro, onde foi curado e tomou ciência de que deveria ser iniciado na religião dos orixás; o que aconteceria, provavelmente, em 1930. Como boa parte da história de João, a da sua iniciação também é controversa. João, em entrevista dada ao jornal Diário da Noite, em matéria que chamava a atenção para a sua pouca idade para comandar um terreiro, fala da madrinha como a responsável por sua iniciação. Em nenhum momento, João diz que ela foi a pessoa que o iniciou, ou que foi sua mãe de santo. Ainda assim, tal fato levou pesquisadores a chamarem atenção para a incongruência e contradição dos relatos sobre sua iniciação (cf. GAMA, 2012).

No candomblé foi que eu soube que estava sendo perseguido pelo meu santo. A mãe-de-santo de lá era minha madrinha, feita de Yansã. Ela me obrigou a 'fazer' o santo. Acontece que, pouco depois, ela morreu e eu tive de substituí-la na chefia do Candomblé (Diário da Noite, 9 set. 1936). 


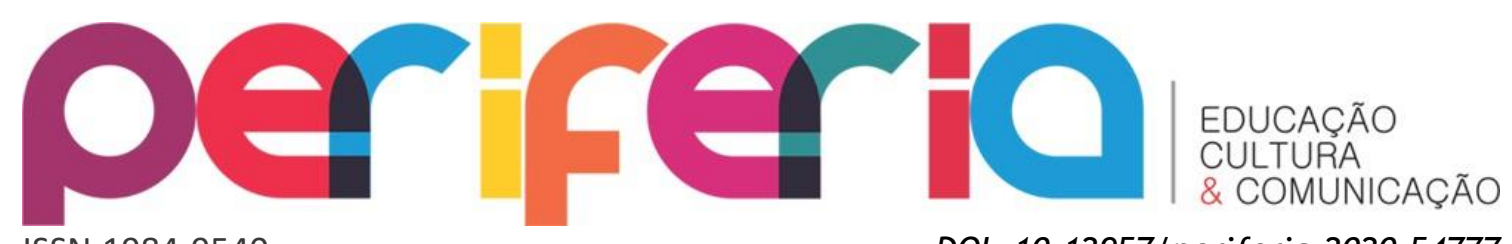

ISSN:1984-9540

DOI: $10.12957 /$ periferia. 2020.54777

Há uma matéria no jornal Correio da Manha ${ }^{6}$, feita a partir de entrevista com João, que afirma que ele fora iniciado pelo renomado pai de santo Severiano Jubiabá, em feitura que teve início em junho e terminou em dezembro de 1930. Entrevistas concedidas por suas filhas de santo também afirmarão que João fora iniciado por Jubiabá. As pesquisas sobre João, ao tratarem o tema da sua iniciação, reconhecem a controvérsia do tema; contudo, poucas se situam entre as duas possibilidades de iniciação, já que a grande maioria afirma que João fora feito por Jubiabá (NASCIMENTO, 2003; SANTOS, 2008; GAMA, 2012; MENDES, 2012; à exceção de GAMA, 2012, como citado).

João era neto de uma mulher ex-escravizada, praticante da religião dos orixás, que previa que ele, mais cedo ou mais tarde, daria continuidade ao culto. Há quem credite o conhecimento de João como tendo sido adquirido através dessa avó. De todo modo, todas as pesquisas sobre João falarão da importância da madrinha para inseri-lo nas "coisas" da religião. Jovem, João dará consultas com o caboclo Pedra Preta, ainda no terreiro herdado da madrinha. A procura é tanta que, pouco tempo depois, João abrirá seu próprio terreiro, em São Caetano.

O II Congresso Afro-Brasileiro, realizado em 1937, em Salvador, é importante evento para dar visibilidade a João da Goméia. O evento eleva João à categoria de apoiador do projeto do etnólogo Édison Carneiro, além de lançar para o mundo a plasticidade das vozes do terreiro da Goméia (incluindo a sua), através de um programa com expressiva audiência na Rádio Comercial, PRF8, onde João, junto com filhas de santo e ogãs da Goméia, cantou para o público ouvinte cantigas de orixás como ouvidas nos terreiros. Antes mesmo de ocorrer, $O$ Estado da Bahia diria: "Assim, a noite africana da Radio Comercial está fadada a um sucesso sem precedentes na história das nossas broadcastings"7. O sucesso da transmissão "trouxe à tona o debate sobre a dessacralização dos cânticos sagrados - mal sabendo seus interlocutores que,

\footnotetext{
${ }^{6}$ Correio da Manhã, Rio de Janeiro, 23 dez. 1955.

7 "Uma noite africana na Rádio Comercial: o pai de santo João da Pedra Preta, com a sua orquestra de negros, executará músicas religiosas dos candomblés". O Estado da Bahia, 12 dez. 1936.
}

Periferia, v. 12, n. 3, p. 94-128, set./dez. 2020 


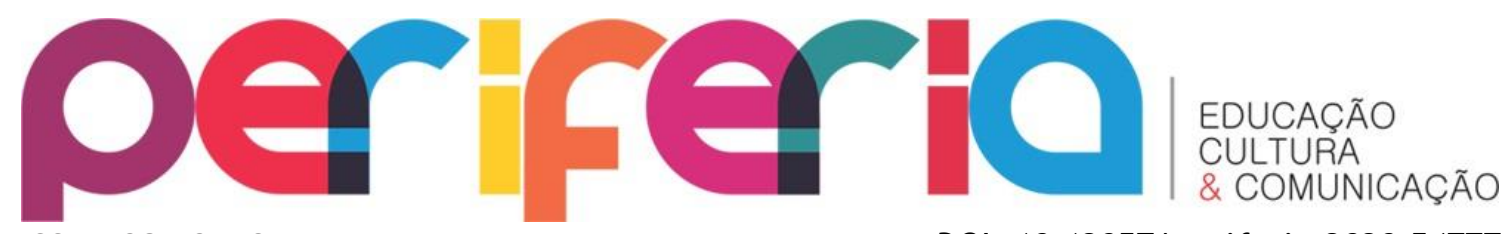

ISSN:1984-9540

DOI: $10.12957 /$ periferia.2020.54777 anos mais tarde, esses mesmos cânticos seriam registrados em discos em vinil e, tempo depois, em compact disc (CD)” (FREITAS, 2003, p. 73). Uma matéria no mesmo $O$ Estado da Bahia descreve a importância do evento:

O pai de santo João da Pedra Preta, chefe do candomblé da Goméia, na Estrada de Rodagem Bahia-Feira, levou para o estúdio da emissora a sua orquestra de negros, dando início, às $21 \mathrm{~h}$, à audição de cânticos religiosos africanos ou de origem africana da Bahia. João da Pedra Preta cantou, anteontem, o despacho de Exu e várias canções de Ogum, Oxóssi, Xangô, de Oxalá, Omolu, Oxunmaco [sic] e de lansã, todas em Ketu, língua norte africana, e canções de Oxóssi, de Nanã, de Oxum, de Tempo, de Katendê e de lansã, em Kinbundu, língua de Angola. Os negros do candomblé da Goméia, sob a direção de João da Pedra Preta, cantaram ainda algumas canções na língua dos caboclos do Brasil ("A noite africana da Rádio Comercial da Bahia: o sucesso inigualável alcançado pelos cânticos religiosos do pai de santo João da Pedra Preta". O Estado da Bahia, 17 de dezembro de 1936).

Édison Carneiro, não por acaso, mantinha uma coluna de crônicas no mesmo jornal. Édison é, nesse momento, o articulador da ponte que unirá lideranças de terreiro e academia. Desse II Congresso, participarão importantes lideranças religiosas, entre essas: Mãe Aninha, ialorixá do Ilê Axé Opô Afonjá; Martiniano Eliseu do Bonfim, renomado babalaô; Manoel Bernardino da Paixão, babalorixá do Terreiro Bate Folha; Mãe Menininha, ialorixá do Terreiro do Gantois; e o próprio Joãozinho, babalorixá do Terreiro da Goméia.

A relação entre Édison e João era marcada por um jogo de interesses que, ao mesmo tempo em que dava certa visibilidade a João, aproximava Édison dos cultos de origem congo angola - mesmo que Édison encarasse João "como um sacerdote menor, se referindo a ele muitas vezes com um toque de humor e ironia” (MENDES, 2012, p. 62). O fato é que esse tipo de associação não era um atributo único do relacionamento com Carneiro. Muitas das relações estabelecidas entre João e outros intelectuais da época também seriam marcadas por um jogo de interesses dos pesquisadores que, mesmo que acreditassem que o culto realizado por João era impuro, não questionavam o conhecimento de João sobre as coisas do mundo dos inquices,

Periferia, v. 12, n. 3, p. 94-128, set./dez. 2020 


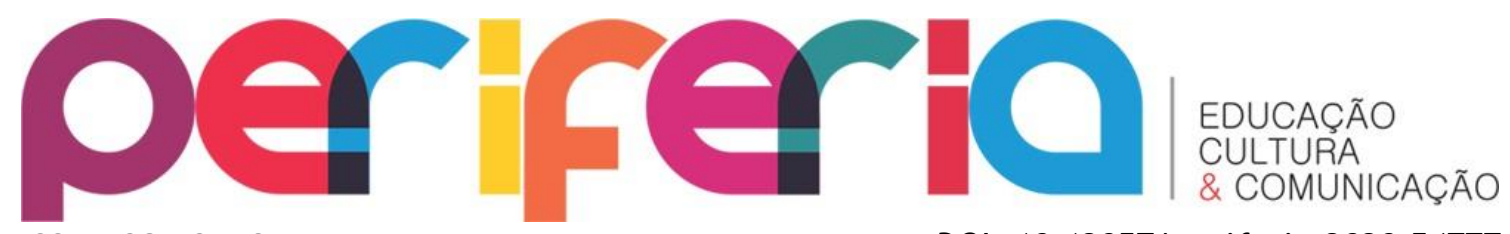

ISSN:1984-9540

DOI: $10.12957 /$ periferia.2020.54777

orixás, caboclos, das divindades afro-brasileiras. O trecho da obra de Jorge Amado, em que João é citado, é ilustrativo.

Outros candomblés podem ser mais puros no seu rito, o do Engenho Velho certamente o será. Também o Axé do Opô Afonjá, o grande templo da mãe-de-santo Aninha, uma das mais formosas, nobres e dignas mulheres que conheci. Seu enterro teve um acompanhamento de milhares de pessoas. Porém nenhuma macumba tão espetacular como essa da roça da Goméia, ora nagô, ora angola, candomblé de caboclo quando das festas de Pedra-Preta, um dos patronos da casa. Nos ritos nagôs, os santos do pai-de-santo da Goméia são Oxóssi e Yemanjá; do pai-de-santo Joãozinho da Goméia ou da Pedra-Preta, um maravilhoso bailarino, digno de palco de grandes teatros. Esse caminho de São Caetano, que leva à estrada difícil da Goméia, é percorrido por quanto artista, quanto escritor e quanto sábio passa por essa cidade (Amado, 1991, p. 154).

Nesse sentido, se atributos qualitativos atribuídos a João pelos pesquisadores podiam ser extremamente negativos, características valorativas de positividade também eram recorrentes nas descrições sobre João. Ou seja, a responsabilidade a João conferida pelos pesquisadores pelo fato de realizar, segundo estes, um culto impuro, degenerado, sincrético, misturado, deturpado, além da sua fraca autoridade, do seu desrespeito à hierarquia, da sua origem e filiação religiosa questionáveis, era, radical e antagonicamente, abrandada pela sua competência para realizar cerimônias espetaculares, sobretudo no que se refere à composição estética desses eventos, assim como à sua simpatia e beleza e ao seu dom para a boa dança.

Os termos que descrevem a figura (e personalidade) de João são paradoxais. São termos valorativos, que emitem juízo de valor calcados numa análise moral e ética, tanto em termos religiosos quanto em termos pessoais e sociais. João seria, assim, um símbolo de pessoa aética e amoral. Noutros momentos, João é ético e pessoa de princípios.

Com a imprensa da época não era diferente. Termos como feitiçaria, mistificação, charlatanismo, falso espiritismo e toda a sorte de adjetivos 


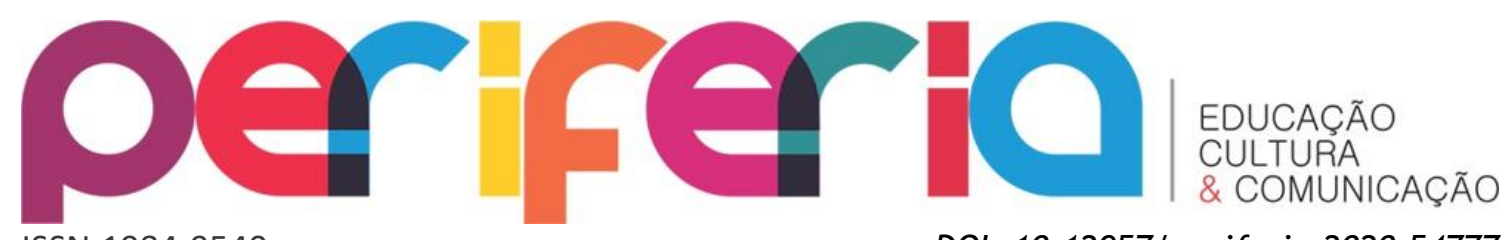

ISSN:1984-9540

DOI: $10.12957 /$ periferia.2020.54777 desqualificantes eram atribuídos a João e à sua religião, em contraposição às qualificações positivas concedidas a ele e a seu terreiro por essa mesma imprensa apoiada pela indústria de entretenimento (televisão, discografia e cinema).

Cabe destacar que, a partir do II Congresso Afro-Brasileiro, além de Édison Carneiro, João criaria articulações com outros pesquisadores e intelectuais baianos ou de passagem pela Bahia. Entre esses, Jorge Amado (1991), que o cita em livro escrito em 1944; Ruth Landes (2002), que falará de João em livro resultante de pesquisa feita em 1939; Lorenzo Turner, que recolhe gravações e fotografias de João e da Goméia, entre 1940 e 19418; Roger Bastide (1995), em obra publicada em 1960; Donald Pierson (1971), em pesquisa realizada na década de 1930 , em que o coloca ao lado de prestigiadas lideranças e terreiros; e o próprio Édison Carneiro (1937), em obra onde relata cânticos ouvidos e cerimônias assistidas no terreiro de João; todos produzindo dados sobre um João, no mais das vezes, retratado como pessoa excêntrica e polêmica. Esse tipo de produção funcionou, anos depois, como importante incremento para impulsionar o nome de João para o mundo, muito próximo da lógica do "falem mal, mas falem de mim" 9, fazendo de João tanto pessoa como personagem. 0 fato é que aquilo que foi visto como degenerado acabou, sobretudo após a morte de João, se transformando em modelo de culto tradicional e marcando uma importante linhagem de santo no Brasil. Essa, mais uma ilustração das muitas contradições que marcaram a história de Joãozinho da Goméia.

Um mulato da Bahia, o famoso João da Goméia trouxe, os ritmos da macumba e do mistério das florestas da sua terra. É o criador do "Bravum", com que será fechado o primeiro ato e que sem dúvida alguma despertará, pela sua beleza de movimento e pelo estranho de sua música, os aplausos da plateia (Correio da Manhã, 10 dez. 1947) ${ }^{10}$.

\footnotetext{
${ }^{8}$ Parte desse material foi reunido pelo pesquisador Xavier Vatin (2017) em forma de um catálogo e quatro CDs.

${ }^{9}$ Sobre ejó, fofoca e mídia, ver: Freitas, 2019.

${ }^{10}$ Matéria sobre espetáculo no Teatro Municipal, que contou com orquestra de sessenta integrantes sob regência do maestro Martinez Grau e com participação do cantor Vicente Paiva, que lançou samba novo durante o evento.
} 


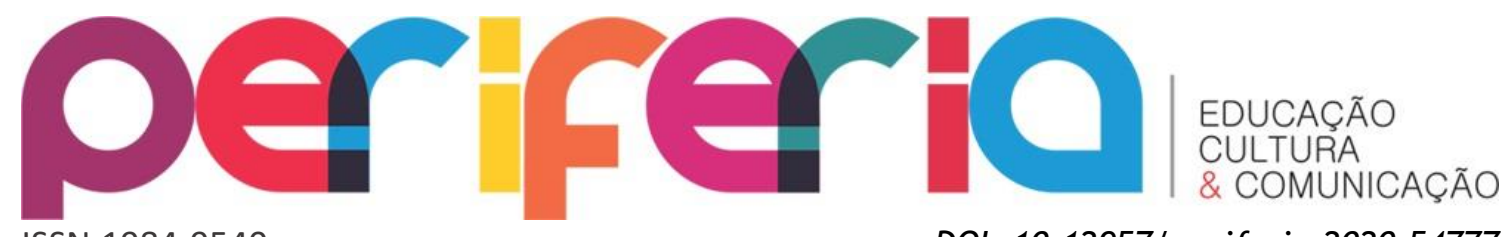

Filho de Gongobira ou Oxóssi e Bamburucema ou lansã, João foi fortemente influenciado, em termos comportamentais, pelas qualidades atribuídas aos filhos protegidos por essas divindades. Com a vida marcada pelas muitas controvérsias acerca da sua história e origem, espiritual ou não, é correto afirmar que João foi, sobretudo, um construtor de fatos, de narrativas controversas, de dissensões, o que the atribuiu o elemento necessário para perdurar como foco de interesse da mídia e da produção científica até hoje.

\section{0 que é que o baiano tem?}

João foi exímio dançarino. Gostava de dançar, sobretudo, as danças que davam forma ao seu modo de religiosidade. Há relatos sobre a excelência do seu dom para a dança ainda na década de 1930, quando a pesquisadora norte-americana Ruth Landes (2002, p. 303) relataria que João “dança maravilhosamente bem", que "é um excelente dançarino e tem certo encanto". Jorge Amado (1991, p. 154) também o descreverá como "um maravilhoso bailarino, digno de palco de grandes teatros". Também há registros de que Joãozinho teria organizado, em 1946, uma grande festa em importante teatro da cidade de Salvador, o Teatro Jandaia, como despedida da Bahia à época da sua mudança definitiva para o Rio de Janeiro ${ }^{11}$. Outras fontes tratam da admiração da Rainha Elizabeth II pela dança de João, quando de sua visita ao Brasil, em 1968 ${ }^{12}$. João foi amigo, inspirador das pesquisas e mestre de Mercedes Batista, precursora do balé e da dança afro no Brasil. João pisou no palco de grandes casas de espetáculo e teatros, tais como o Teatro João Caetano, o Cassino da Urca, o Teatro Cassino Atlântico, o Hotel Quitandinha (dos quais foi coreógrafo contratado) e frequentou o Copacabana Palace $^{13}$. Bebeu na fonte do teatro de revista, se apresentou em casas de show, além do fato de ter sido professor de dança e apaixonado pelo

\footnotetext{
${ }^{11}$ Ver: Nascimento, 2003, p. 49.

${ }^{12}$ Ver: Mendes, 2012, p. 70.

${ }^{13}$ Ver: Nascimento, 2020.
}

Periferia, v. 12, n. 3, p. 94-128, set./dez. 2020 


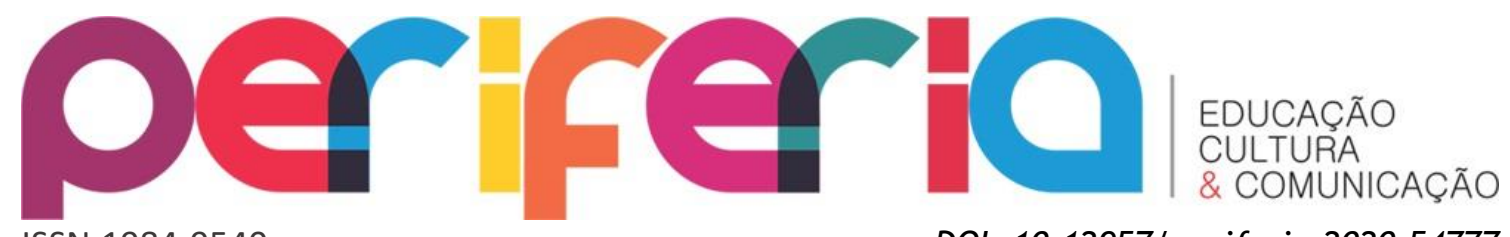

ISSN:1984-9540

DOI: $10.12957 /$ periferia.2020.54777 carnaval, o que causou crítica ao seu desejo de transformar, segundo alguns, o candomblé em teatro, em espetáculo, de carnavalizar o sagrado. Suas aptidões para a arte estavam estritamente relacionadas às coisas do santo, às práticas e imaginários do universo religioso, em clara alusão ao fato de que a arte não está separada nem da religião nem da vida. A entrevista concedida em matéria ao jornal $O$ Estado da Bahia é ilustrativa:

Por mim, farei o que puder pelo Congresso. Já prometi a Edison Carneiro, encarregado do Congresso, dar uma festa aqui aos intelectuais, mandar alguns orixás e alguns instrumentos para a exposição, aparecer nas sessões e levar gente para assistir os trabalhos. Já é coisa, hein? Tenho, por exemplo, uma imagem de Anamburucú muito velha. Essa vai para o Congresso ("O mundo religioso do negro da Bahia". 0 Estado da Bahia, 7 ago. 1936).

Há fontes que mostram a boa relação de Joãozinho com renomados artistas da sua época ${ }^{14}$. Entre esses, a cantora mexicana Mexicanita; a cantora brasileira Angela Maria; o cantor Cauby Peixoto; a cantora Elza Soares; a vedete e cantora Marlene; a dançarina Eros Volúsia; o ator Grande Otelo; a atriz, dançarina e cantora norte-americana Ginger Rogers; a atriz cubana radicada no México Ninón Sevilla e tantos outros artistas que ocupavam a esfera de visibilidade midiática à sua época. João também é citado entre personalidades as mais distintas no comparecimento ao funeral de Carmen Miranda.

${ }^{14}$ Ver: Ferreira, 2016.

Periferia, v. 12 , n. 3, p. 94-128, set./dez. 2020 


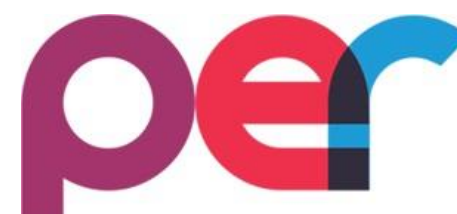

ISSN:1984-9540

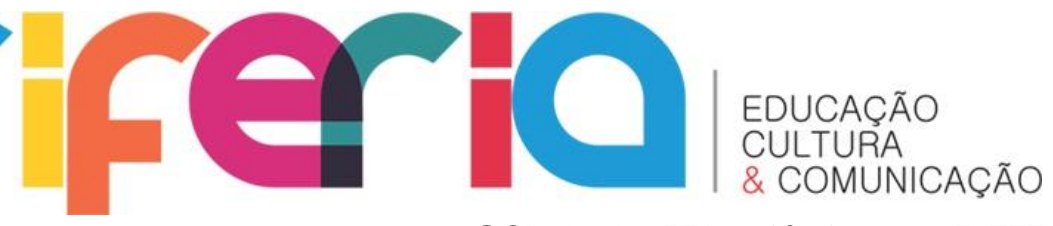

DOI: $10.12957 /$ periferia.2020.54777

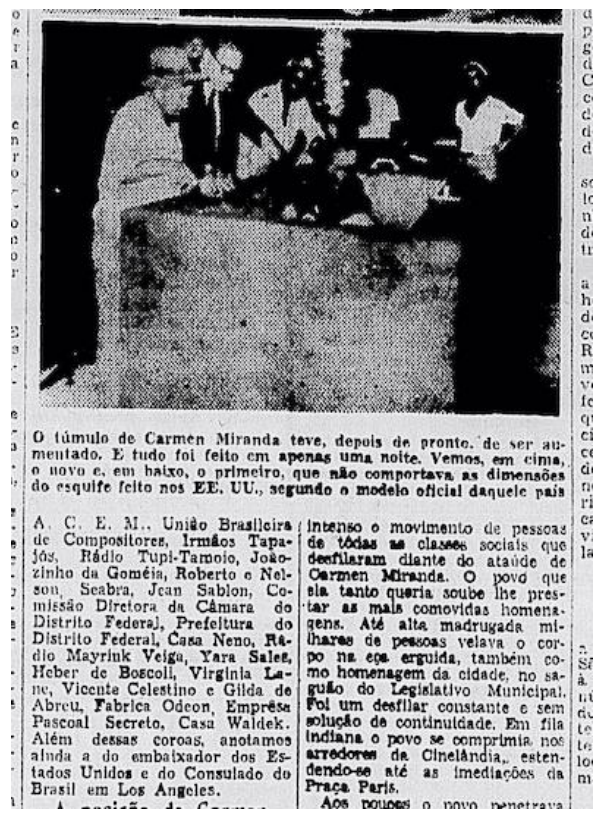

A Noite. 13 ago. 1955 , p. 5.

Algumas personalidades chegarão mesmo a ocupar cargos dentro do terreiro de João. Jorge Amado, em entrevista concedida a Alice Raillard, cita a Goméia como um dos terreiros ao qual estava filiado:

A luta de toda a minha vida contra o racismo é uma luta que apóia diretamente a religião negra. Evidentemente por essa razão fui designado; eu já tinha outros títulos: fui ogã de Oxóssi no candomblé do Procópio, ogã de lansã no candomblé de Joãozinho da Goméia, um candomblé de caboclo, e finalmente obá (RAILLARD, 1990, p.82).

João recebeu na Goméia fluminense o presidente Getúlio Vargas e foi convidado por Juscelino Kubitschek a ir até o palácio presidencial, segundo relato da embaixatriz da França no Brasil, Gisele Cossard Binon ${ }^{15}$, que seria iniciada, ela mesma, na religião dos orixás pelas mãos de Joãozinho, quando recebe o nome africano Omindarewa - o que comprova o trânsito e as articulações entre João e importantes personalidades do cenário político brasileiro e internacional, assim como o seu bom relacionamento junto à

\footnotetext{
${ }^{15}$ Em depoimento dado a Fichte, 1987, p. 67.
}

Periferia, v. 12, n. 3, p. 94-128, set./dez. 2020 


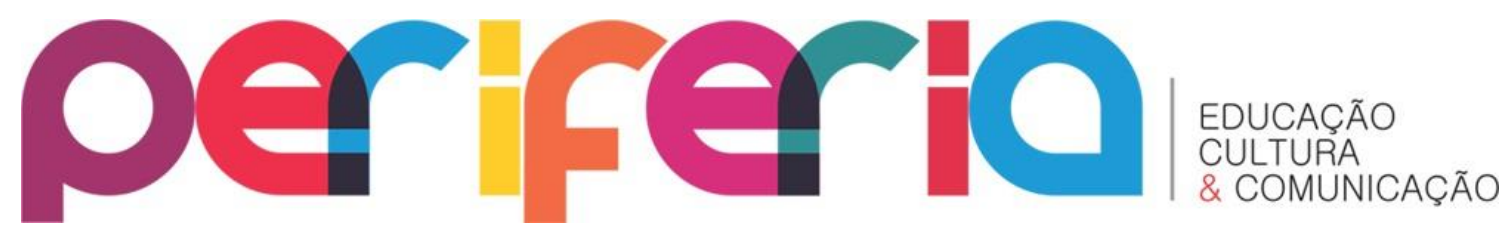

ISSN:1984-9540

DOI: $10.12957 /$ periferia.2020.54777

diplomacia, por conta da sua simpatia, educação e inclinação para a promoção de eventos.

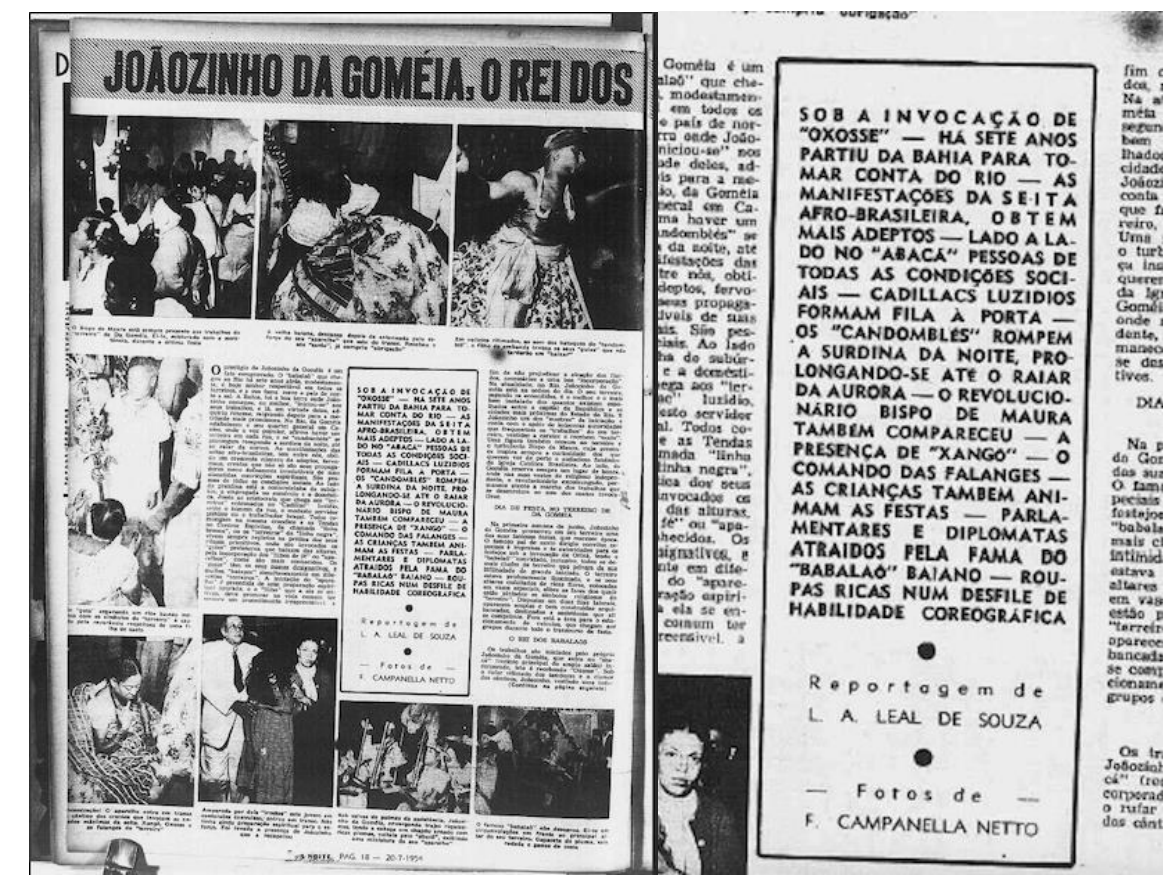

Joãozinho da Goméia, o Rei dos Babalaôs. A Noite. 20 jul. 1954. Detalhe da matéria.

João também participaria como bailarino da Companhia Baiana de Folclore Oxumarê e organizaria exposições de vestimentas de orixás à época dos festejos em seu terreiro, o que ilustra o seu dom para a produção e a organização de eventos culturais e artísticos, onde a estética e a plasticidade dos terreiros davam o tom. Essa inclinação para o espetacular e fenomenal leva João diretamente para o carnaval. Torna-se destaque do Império Serrano, que acompanhou desde a fundação. Anos mais tarde, em 1970, descontente com a Escola, desfilará pela Imperatriz Leopoldinense, outra escola verde e branco, as cores do seu orixá. Comparece ao Baile do João Caetano fantasiado de Arlete, o que provoca repúdio no meio religioso à figura do religioso carnavalesco e exalta a estreita relação entre o candomblé e "outros aspectos da cultura brasileira", incluindo-se aí "as festas populares" (LODY; SILVA, 2002, p. 162). 


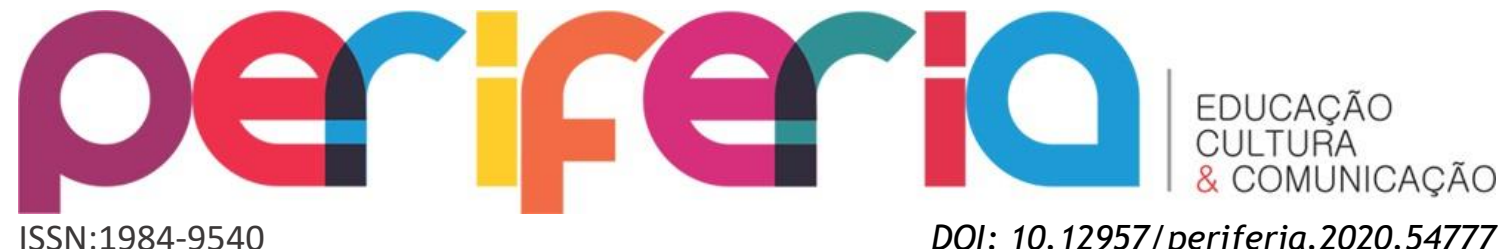

Lançou dois discos em 78 rotações (rpm), em 1956, com um cântico para lansã, dois para Oxóssi e um para o Caboclo Pedra Preta. Chamou todas as músicas de "Saudação", num tipo de adaptação livre. Em 1958, lançou o long play "Rei do Candomblé: Joãozinho da Goméa com ritual de Terreiro", com doze músicas de sua autoria, relançado em 1962 e 1971.

João encontra nessa brecha, no consumo do entretenimento e da indústria cultural, o caminho para espetacularizar o advento religioso. Para tanto, faz exaltação do caráter espetacular, luxuoso, apoteótico, cênico e lúdico do candomblé, através do uso e do abuso da estética e plasticidade relacionadas às formas de culto, promovendo um tipo de candomblé arte, num momento em que no Brasil a ideia do futebol arte e da música espetáculo (com a organização dos aclamados festivais) estava em voga.

Ao colocar o candomblé na cena do show business, João não somente alimentou o desejo de tornar-se artista, como também deu visibilidade ao candomblé através daquilo que tratamos como sendo digno da entrada do candomblé "pela porta da frente", isto é, da positivação de religiões durante muito tempo tidas como degeneradas, da exaltação de religiões antes vistas através de representações deturpadas, negativadas e desqualificadas.

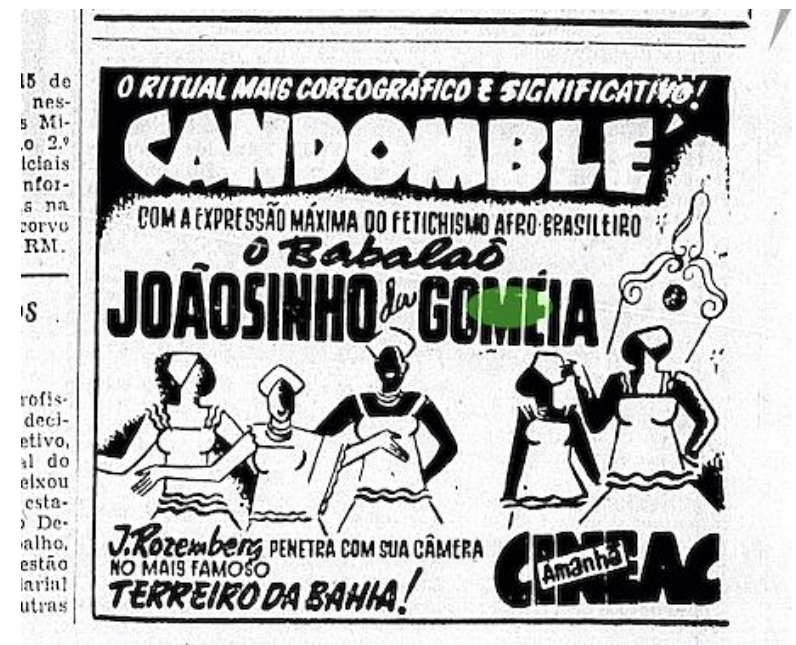

A Noite. 11 abr. 1956.

Periferia, v. 12, n. 3, p. 94-128, set./dez. 2020 


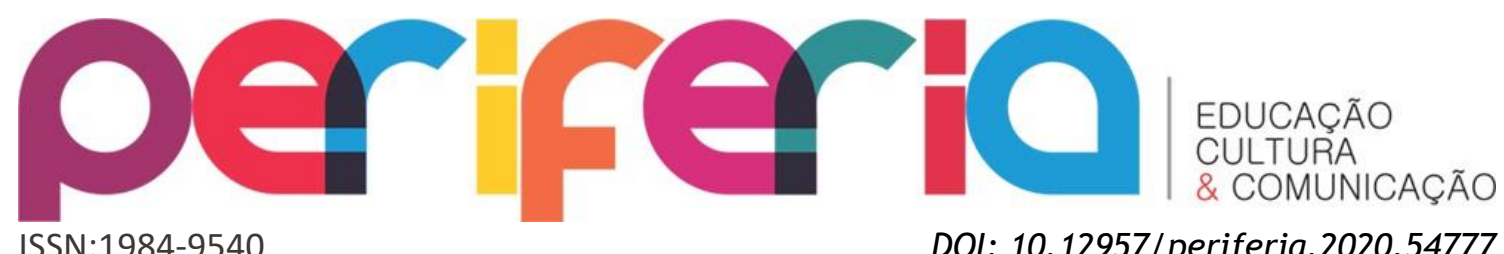

É Pedra Preta, quem risca ponto nesta casa de caboclo

Julho de 2020. Uma avalanche de mensagens de repúdio à ideia capitaneada pela prefeitura do município de Caxias de construir uma creche no antigo terreno do terreiro da Goméia foi compartilhada nas mais distintas redes sociais. A ideia do prefeito trouxe à tona, mais uma vez, o nome da Goméia de João à cena pública. Também mostrou, mais uma de muitas vezes, a importância do acionamento da mídia como força combativa a qualquer tentativa de negativar o nome e a memória de João e da Goméia. A mídia, sempre ela, junto com importantes iniciativas empreendidas pelo mundo das artes e pela academia, serviu como campo de batalha no combate ao projeto da prefeitura que contribuiria para profanar o maior símbolo da memória material e simbólica da Goméia, seu antigo terreno.

Um mês após o imbróglio ${ }^{16}$, em pesquisa no buscador Google, o mais usado site de serviço de busca na Internet, foram encontradas 254 publicações que fizeram uso da hashtag \#tombagomeia; 339 publicações apareceram para a busca tombagomeia sem o uso da hashtag; 27.000 menções à Goméia, 1.150 menções à Goméia mais creche; 1.450 para Gomeia (sem acento) mais tombamento; 6.250 para João da Goméia; 22.700 para Joãozinho da Gomeia (sem acento) e 23.900 para Caxias mais Goméia. Esses números não consideram as menções ao caso nas redes sociais Facebook e Instagram, já que tal levantamento demandaria o uso de programas mais complexos para monitoramento e levantamento dos dados, mesmo reconhecendo que as redes sociais foram as plataformas mais utilizadas na campanha alimentada pela hashtag \#tombagomeia e que isso poderia apresentar números muito mais relevantes. De todo modo, os números são absolutamente expressivos frente, por exemplo, às buscas por outros nomes importantes para o universo religioso afro-brasileiro que viveram à época de João. Tudo isso acontecendo em um ano em que Joãozinho da Goméia foi tema de escola de samba e tema

\footnotetext{
${ }^{16}$ Busca realizada no dia 23 de agosto de 2020.
}

Periferia, v. 12, n. 3, p. 94-128, set./dez. 2020 


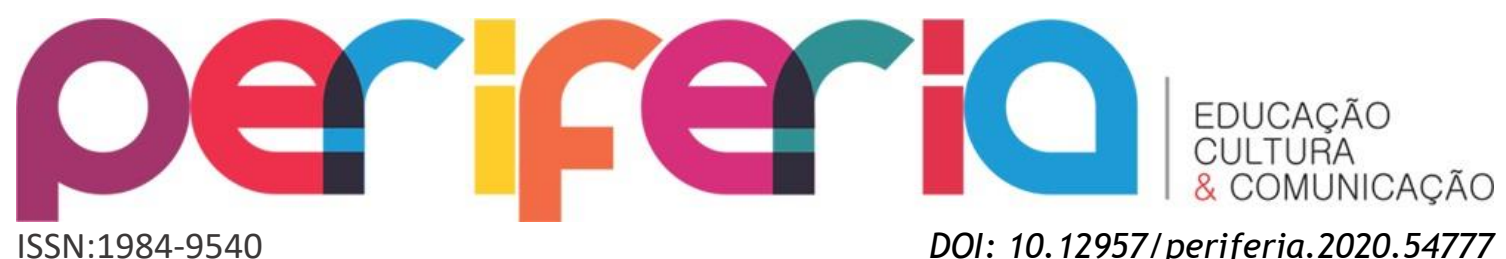

de filme. Tanto o filme ${ }^{17}$ quanto o enredo da escola de samba ${ }^{18}$ também foram importantes eventos para reivindicar a proteção do antigo espaço físico do terreiro e a transformação do espaço em centro cultural e centro de memória de Joãozinho e da Goméia, permitindo entender a importância de João e da Goméia para a cultura caxiense, baiana e, por extensão, brasileira.

Ao analisarmos o movimento de denúncia da violência que seria praticada, como acreditavam alguns, caso o antigo terreno fosse transformado numa creche, entendemos que o uso da mídia como ferramenta de combate a uma ação violadora da memória de João e da Goméia se consolidou na mais ampla tradução de mídia: filme, samba, escola de samba, Internet, redes sociais, jornais on-line, jornais impressos, TV e uma série de outros recursos. O movimento também chama a atenção para o fato de que, ao acionarmos tais recursos (de mídia) nos aproximamos, ou melhor, repetimos o feito por João a partir dos longínquos idos de 1930, quando tenta adquirir legitimidade junto à esfera de visibilidade midiática e, por extensão, à esfera pública política. Mesmo que agora as motivações e intenções sejam distintas, é a mesma mídia e esfera pública, modificadas pelos avanços inerentes às transformações impactadas pela história social e pelos avanços nos meios de comunicação, que mobilizarão um sem número de pessoas em torno da causa \#tombagomeia.

\section{Baixar no terreiro quilombo Caxias}

Ocupar espaço junto à mídia sempre significou para o povo de santo uma conquista relevante. Primeiro, pelo fato óbvio de se ver representado, na lógica de que representatividade é importante, sobretudo para pessoas que poucas vezes se viram positivamente representadas. Segundo, e também por isso, pelo fato de que, como essas representações nem sempre foram positivas e recorrentemente apresentaram as religiões afro-brasileiras como religiões

\footnotetext{
${ }_{17}$ Joãosinho da Goméa - O rei do candomblé. Documentário. Dir.: Janaína Oliveira Refém e Rodrigo Dutra. 2019.

${ }^{18}$ Tata Londirá: o canto do Caboclo no Quilombo de Caxias. Enredo: Leonardo Bora e Gabriel Haddad. Grêmio Recreativo Escola de Samba Acadêmicos do Grande Rio. 2020.
}

Periferia, v. 12, n. 3, p. 94-128, set./dez. 2020 


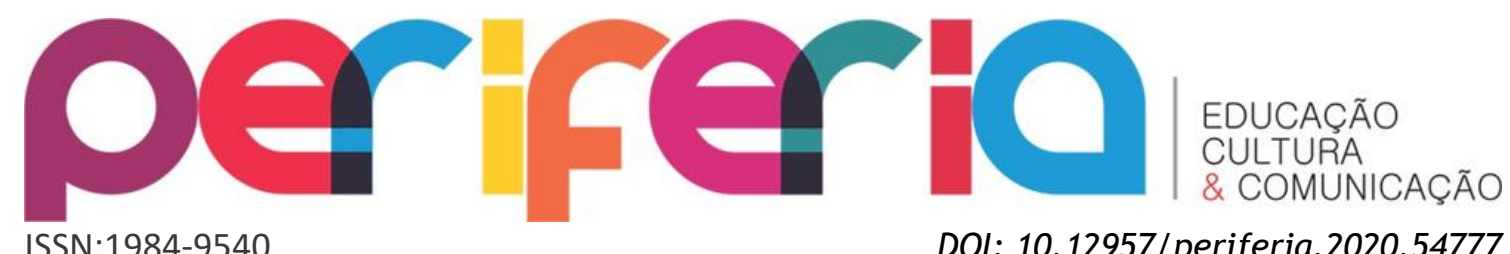

relacionadas ao ilícito, à barbárie e à feitiçaria, tal fato provocou, entre seus fiéis, um tipo de avidez por representação positiva movida pela repulsa, reparação e compensação. Afinal, a mídia e todos os seus produtos, mesmo quando prometeram produções respeitosas e favoráveis a essas religiões, em termos de representação, quase nunca corresponderam às expectativas dos seus integrantes, como no clássico caso das telenovelas.

A imprensa, por sua vez, esteve articulada aos ideais propostos pela medicina legal e suas escolas, assim como pela polícia com suas batidas que, recorrentemente, citaram o candomblé como religião de desvio, em termos legais, tanto sanitários como jurídicos ${ }^{19}$, sendo desde o século XIX, legitimadora das representações acerca do candomblé como religião degenerada ou lugar de encontro de delinquentes, de prática ilegal da medicina, de encontro de pessoas desrespeitosas das normas, regras de comportamento e leis de boa conduta. Mas a mídia também foi importante instrumento para dar visibilidade às lideranças religiosas e seus terreiros e, por extensão, fazer com que ocupassem lugar privilegiado no mercado de oferta de serviços mágico-religiosos, podendo assim-participar dos circuitos de trocas, tão característicos dessas religiões, com mais prestígio, privilégio e poder (inclusive, econômico). Nesse sentido, a inserção de Joãozinho no mundo do consumo, no mundo comunicacional e no mundo das imagens não pode ser dissociada da sua árdua conduta para ocupar a esfera de visibilidade midiática e, por extensão, a esfera pública política a fim não somente de positivar religiões representacionalmente negativadas mas, também, de ocupar lugar no mundo das mercadorias, aparentemente incompatível, mas não necessariamente, com o dom, com a dádiva (cf. Mauss, 2003). João, nesse sentido, pode ser considerado a primeira liderança religiosa a assumir, pública e midiaticamente, a harmonia entre o sagrado da religião e a profanidade do interesse capitalista, traduzido pelo acúmulo de capital, pelo dinheiro.

A fama (advinda da visibilidade midiática) como alimentação da vaidade pessoal também pode ser tratada aqui. A vaidade está relacionada à

\footnotetext{
${ }^{19}$ Ver: Serra, 2006; Luhning, 1996.
}

Periferia, v. 12, n. 3, p. 94-128, set./dez. 2020 


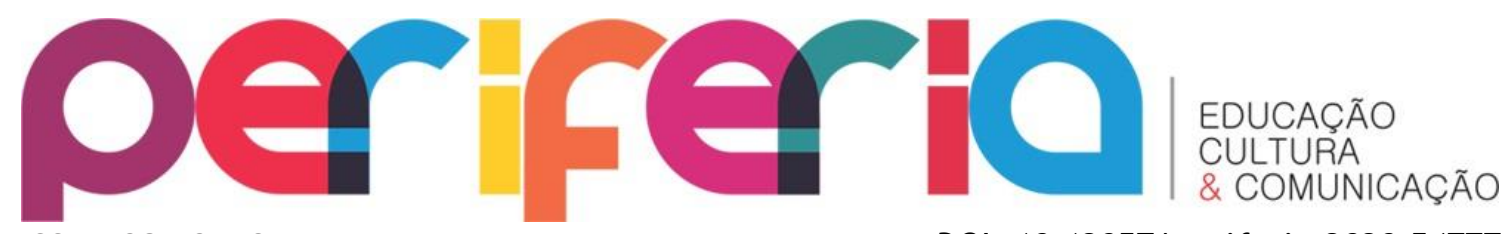

ISSN:1984-9540

DOI: $10.12957 /$ periferia.2020.54777 pura racionalidade e à lógica do interesse, características do mundo da mercadoria, como pensou Simmel (2009) para o caso do dinheiro, parecendo se encontrar dissociada das relações de fé e do domínio da religião, da pureza e da transcendência. Como pecado capital, a vaidade, apoiada pela participação em mídia, movimenta o desejo de ver e ser visto, muito próximo do que pensou Sodré (1984), ao conceber a TV (e digo, a mídia) como uma máquina para escoamento dos desejos subjetivos presentes no imaginário do espectador, o que definiu como sendo a "máquina de Narciso". A mídia, assim, convoca a participação do público e the concede a possibilidade de diálogo e de aparição (permitida) a fim de aumentar a audiência e a efetividade da opinião pública. É, pois, nos interstícios dessa relação promíscua entre receptor passivo e emissor dominante que a vaidade se transforma de pecado em virtude e, por extensão, em carisma, que, apesar de performático, não deveria condizer com a perversa e extravagante lógica do acúmulo do capital, nos termos de Weber (1996). Mas condiz, e alimenta um mercado de fé baseado na fama e no carisma performático, promotores da permanência de uma celebridade na esfera visibilidade midiática, como no caso de João - quanto mais João consolidava seu nome e imagem nos meios de comunicação à sua época, mais essas empresas queriam tê-lo em seus programas, criando assim um tipo de roda viva que exigiu de João uma (re)construção diária da sua personalidade e imagem, muito próxima da busca de popularidade e da exposição do Eu (nas redes sociais), como visto na contemporaneidade. João, nesse sentido, foi tanto pessoa como personagem, criando e recriando um tipo de alter ego erguido pela fama, que fez do mesmo “João-ator-músico-dançarino" um João personagem póstumo de peça teatral, de filme, de escola de samba e de espetáculo de dança.

A fama de João não abasteceu somente o nome de seu terreiro e de sua família de santo, a Goméia, mas serviu também para atribuir status, poder e prestígio a quem dele amigo fosse. Por isso, a visita de João a festas em outros terreiros alimentava o circuito de festividades afro-religiosas fluminenses da época, que ia se readequando à nova realidade do candomblé 


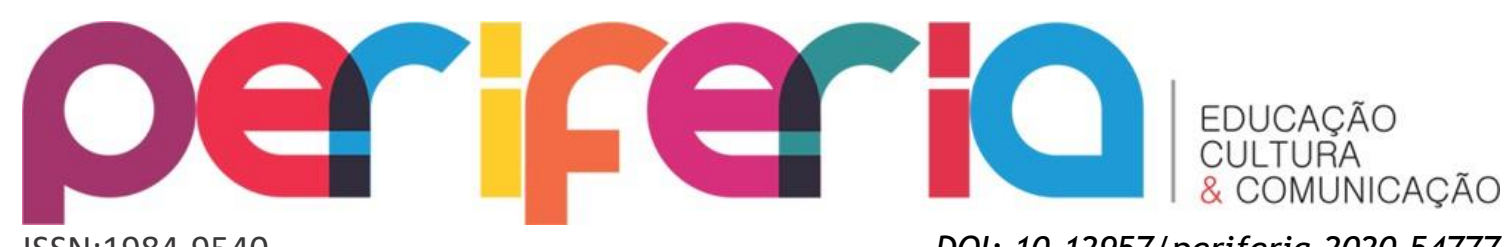

ISSN:1984-9540

DOI: $10.12957 /$ periferia.2020.54777 em diálogo com a classe média brasileira e em articulação com as esferas de poder, privilégio e prestígio. Tal fato muito contribuiu para reconfigurar o campo religioso afro-brasileiro no Rio de Janeiro. Em depoimentos coletados na década de 1990 (FREITAS, 2016), antigos integrantes de terreiros fluminenses falaram sobre a inserção do arroz, feijão, maionese, carnes, saladas e farofa nos jantares servidos aos fiéis após as festas públicas como sendo uma inovação criada por João da Goméia e João Lessengue, outra importante liderança religiosa baiana que irá se fixar no Rio de Janeiro no início dos anos de 1940. A inserção de pratos distintos aos pratos comumente servidos após as festas de santo na Bahia, tratados como "comida de azeite", apagava os traços de nordestinidade, já que se distanciava da realidade baiana, e subtraía da mesa a pujança do azeite de dendê da culinária africana, dissipando os traços de africanismos reservados às divindades. Além disso, mostrava (para fora) a competência daquele terreiro e comunidade para dialogar com outras esferas, nesse caso, de poder e prestígio.

Esfera pública, como conceito proposto por Habermas (1984), é o espaço social da representação (pública), que deve ser gerido pela argumentação, discurso, publicidade e privacidade e que funciona como mediador e lugar de conversa e influência entre o Estado e a esfera privada. A definição do conceito é ilustrativa da importância da ocupação dessa esfera, que é sempre política, já que é lugar de visibilidade de demandas, da exposição de problemas e de prioridades. A esfera de visibilidade midiática assume, assim, o importante papel de tornar acessível o debate público, funcionando como uma ponte entre sociedade civil, sistema político e cultura (cf. MAIA, 2020).

João, ao tentar adentrar a esfera de visibilidade midiática, promoveu, a seu modo, um tipo de contradiscurso, de combate e resistência aos discursos estabelecidos, cristalizados como statu quo, que aqui traduzirei como sendo fruto do racismo anti-negro construído ao longo do século XX, quando, ao deslegitimar as religiões de origem africana no Brasil, promoveu um tipo de manutenção da aversão às “coisa de preto”, à animalidade, à 


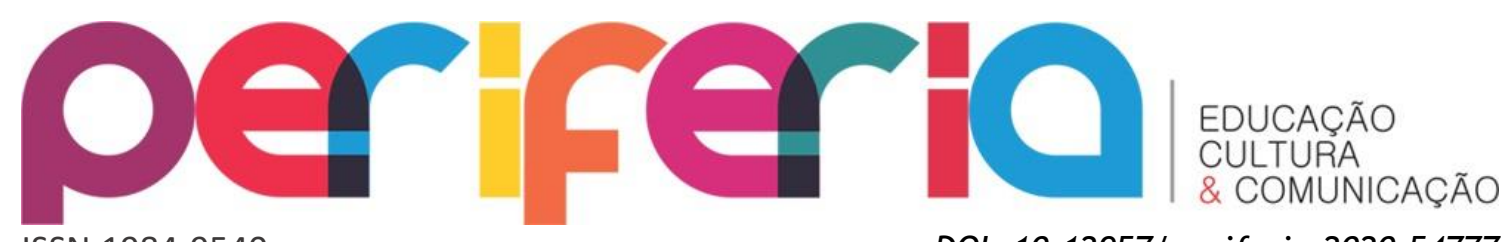

ISSN:1984-9540

DOI: $10.12957 /$ periferia.2020.54777 selvageria e à barbárie, significantes recorrentes nas representações sobre populações afro-diaspóricas no mundo ocidental. Por isso, é correto afirmar que a participação de João na esfera de visibilidade midiática não significou apenas resistência. Sua presença também criou novos discursos e representações sobre ser negro, integrante de religiões afro-brasileiras, nordestino, descendente das classes populares e homossexual. Nesse sentido, além de promover resistência, João promoveu insurgência, já que não investiu tão somente em participar da esfera pública, como também acabou criando um tipo de esfera pública paralela, alternativa, não menos importante para a publicização das religiões afro-brasileiras.

É correto afirmar que a intolerância que se ergueu contra essas religiões, por isso, uma intolerância religiosa, é uma das unidades do racismo estrutural; portanto, um racismo religioso. A intolerância religiosa contra as religiões afro-brasileiras é racista, pois é parte de um projeto de apagamento e repulsa aos vestígios de traços de africanidades que se perpetuaram no Brasil moderno, um projeto de aniquilamento das expressões culturais de matrizes africanas, nesse caso, da cultura religiosa de matriz africana que, apesar de rejeitada, é elemento central na constituição das expressões culturais brasileiras - mesmo não religiosas. Esse projeto de apagamento não se estrutura, especificamente, na ausência; mas, corriqueiramente, na presença apagada, desqualificada (FREITAS, 2020), que muito nos faz lembrar os constrangimentos e coações, tratados por Nancy Fraser (1985) como impeditivos de promoverem a participação igualitária de determinados segmentos populacionais nas deliberações tomadas na esfera pública política.

O conceito de contradiscurso, como defendido por Fraser (1985), se apoia na crítica ao conceito de esfera pública, como pensada por Habermas (1984). Para a autora, a esfera pública burguesa não é unívoca, tampouco universal, como acreditava Habermas. Há grupos que encontram resistência às suas presenças e participações no debate público consensual. Estão, portanto, fora das decisões que consolidam a opinião pública, quando encontram obstáculos para exercer suas cidadanias. Excluídos do debate público e 


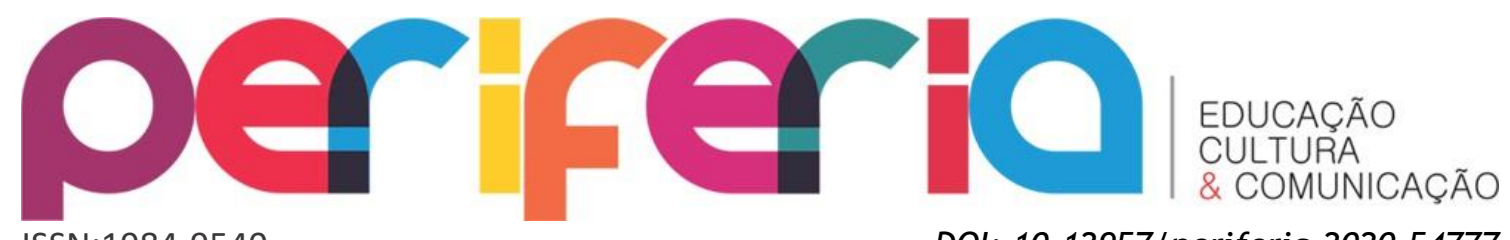

ISSN:1984-9540

DOI: $10.12957 /$ periferia.2020.54777 pressionados pela supressão, tais grupos e comunidades criam o que Fraser (1985) denominará contrapúblicos subalternos, que nada mais são do que arenas discursivas paralelas.

João não estava sozinho na constituição dessa arena paralela. J. B. de Oliveira e Átila Nunes, por exemplo, comandarão programas radiofônicos sobre as religiões de orixás já nas décadas de 1940 e 1950. A MPB, com seus compositores e cantores integrantes das religiões afro-brasileiras, também dará importante contribuição para a produção de uma contra informação sobre essas religiões. Outros babalorixás negros, baianos e cariocas, alguns gays, com prestígio e fama junto ao povo de santo, também ocuparão a esfera de visibilidade midiática no Rio de Janeiro daquelas décadas, contribuindo para a positivação dessas religiões junto à cena pública: o já citado João Lessengue, Álvaro Pé Grande, Tião de Irajá, Tata Fomotinho, Djalma de Lalu, Waldomiro de Xangô, Ninô de Ogun, Caboclo Venta de Axé, Miguel Grosso, José de Obakossô, Zezito de Oxum, Zezinho da Boa Viagem, Francisco de lemanjá, Cristóvão do Pantanal, Ciriáco, Aderman, Xangozinho do Estácio, Vicente Bankolê, Seu Doum, Seu Mirinho d’Oxum, Otávio da llha Amarela, entre outros. Entretanto, João foi precursor, foi o babalorixá que mais tempo permaneceu na esfera de visibilidade midiática, transitando entre muitas (multi) mídias e criando contradiscursos e contranarrativas sobre ser negro, “macumbeiro” e homossexual num Brasil racista, intolerante e homofóbico.

João extrapolou os limites da produção e distribuição de produtos comunicacionais, ao transformar ele próprio, seu terreiro e suas divindades em personagens. O lindo afro-samba Canto do Caboclo Pedra Preta é uma homenagem ao caboclo de João, feita por ninguém menos que Vinicius de Moraes e Baden Powell, como revela Silvia, esposa de Baden.

Ele foi num pai de santo muito famoso chamado João da Gomeia, que tinha uma casa de candomblé em [Duque de] Caxias (RJ) e incorporava o Caboclo Pedra Preta. Quando Baden quis fazer sua música ["Canto da Pedra Preta"], foi perguntar ao João da Gomeia se podia fazer essa homenagem - revela Silvia (FAGUNDES, 2017, p. 29).

Periferia, v. 12, n. 3, p. 94-128, set./dez. 2020 


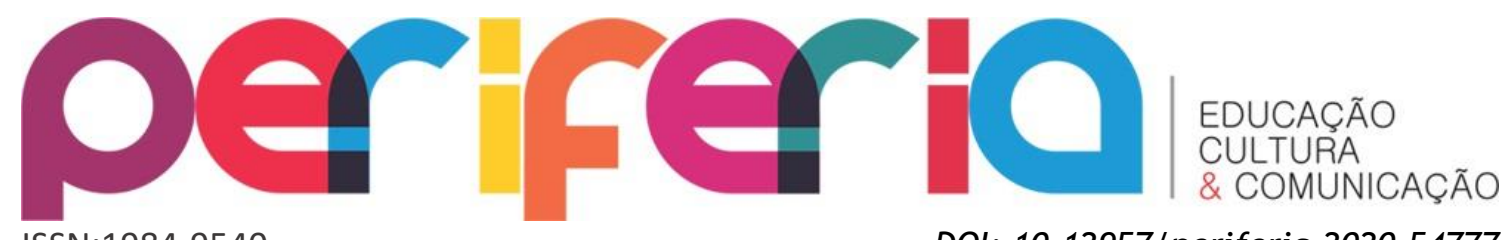

ISSN:1984-9540

DOI: $10.12957 /$ periferia.2020.54777

João foi matéria de capa na revista ${ }^{20} \mathrm{com}$ maior circulação nacional à época. Manteve coluna diária no jornal $O$ Diário Trabalhista, em coluna intitulada "Ao Cair dos Búzios", para onde leitores enviavam cartas juntamente com um pequeno cupom publicado pelo periódico que thes daria direito a sorteios de prêmios ${ }^{21}$. Essa, boa ilustração do modo com que a presença e fama de João ajudavam nas vendas do jornal. João fez cinema, quando se autointerpretou no longa-metragem Copacabana Mon Amour ${ }^{22}$, encarnando um babalorixá que cuidaria dos problemas espirituais da protagonista. Além disso, num momento em que as viagens entre o Rio e o Nordeste eram longas e dificultosas, a ponte marítima estabelecida por João entre o Rio e a Bahia, somente contribuiria para o aumento da fama do já renomado babalorixá.

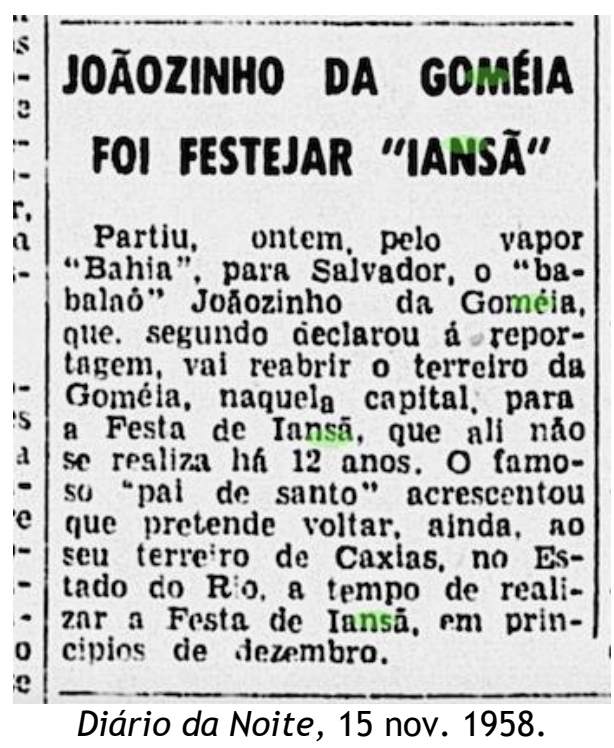

João foi quem melhor atuou como um tipo de ressignificador da imagem que se construiu sobre o candomblé como "coisa de preto" e de delinquentes. Para tanto, João teve a seu favor o fato de ter sido uma pessoa orgulhosa da sua cultura, da riqueza estética e plástica presente nos muitos

\footnotetext{
${ }^{20}$ Revista $O$ Cruzeiro, 23 set. 1967.

${ }^{21}$ Sobre a coluna, ver: Silva, 2010.

${ }^{22}$ Copacabana Mon Amour. Dir.: Rogério Sganzerla. 85 min. São Paulo: EMBRAFILME, 1970.
} 


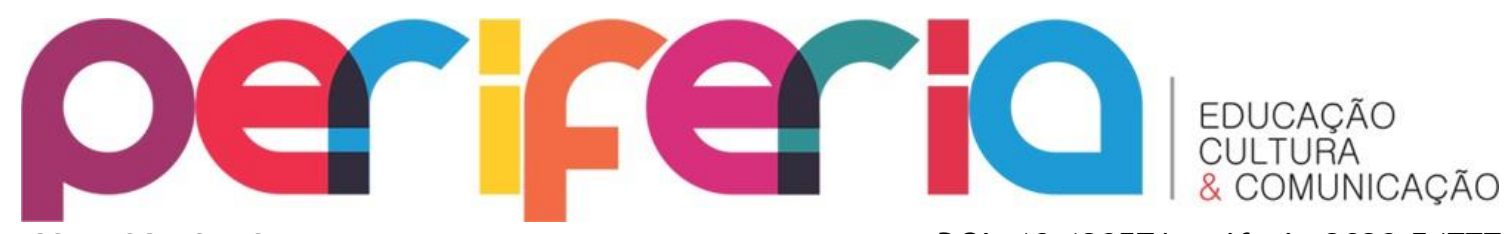

ISSN:1984-9540

DOI: $10.12957 /$ periferia.2020.54777

elementos e expressões que compunham a sua religião - as artes da indumentária, da joalheria, da dança, da música, da culinária etc., fazendo da repulsa, da aversão e do desconhecimento sobre a sua cultura, simpatia, afeição e admiração. João transformou, assim, representações que pareciam imutáveis.

A exaltação das qualidades artísticas de João deu a ele a senha para ingressar na mídia “pela porta da frente" e, ao mesmo tempo, deu à mídia a chave para camuflar a barbárie e rudeza que acreditava estarem embutidas na religião de João, ao apresentá-la como espetacular, luxuosa e original.

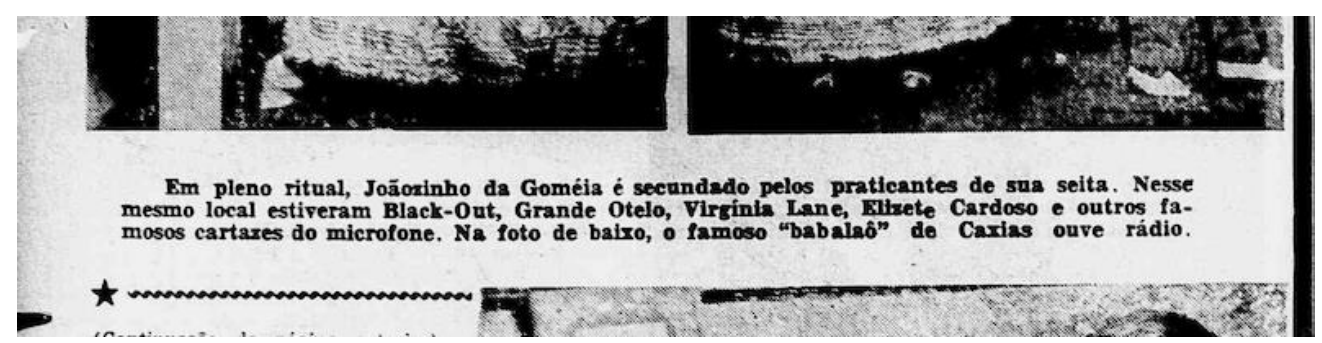

Revista do Rádio. 6 mar. 1954. 


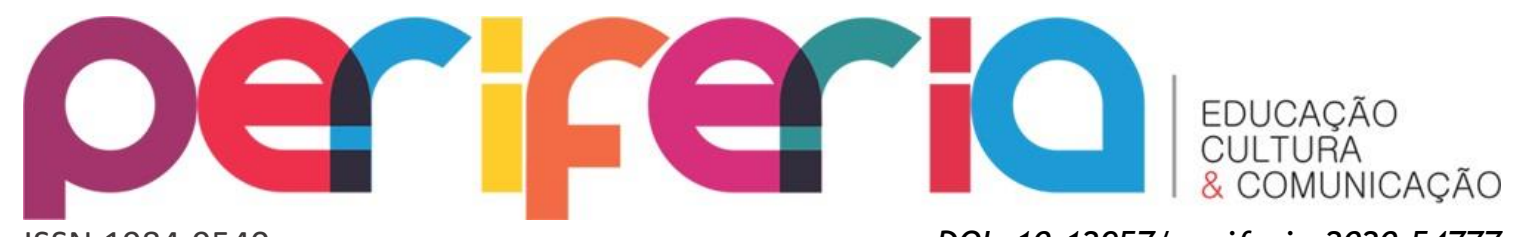

ISSN:1984-9540

DOI: $10.12957 /$ periferia.2020.54777

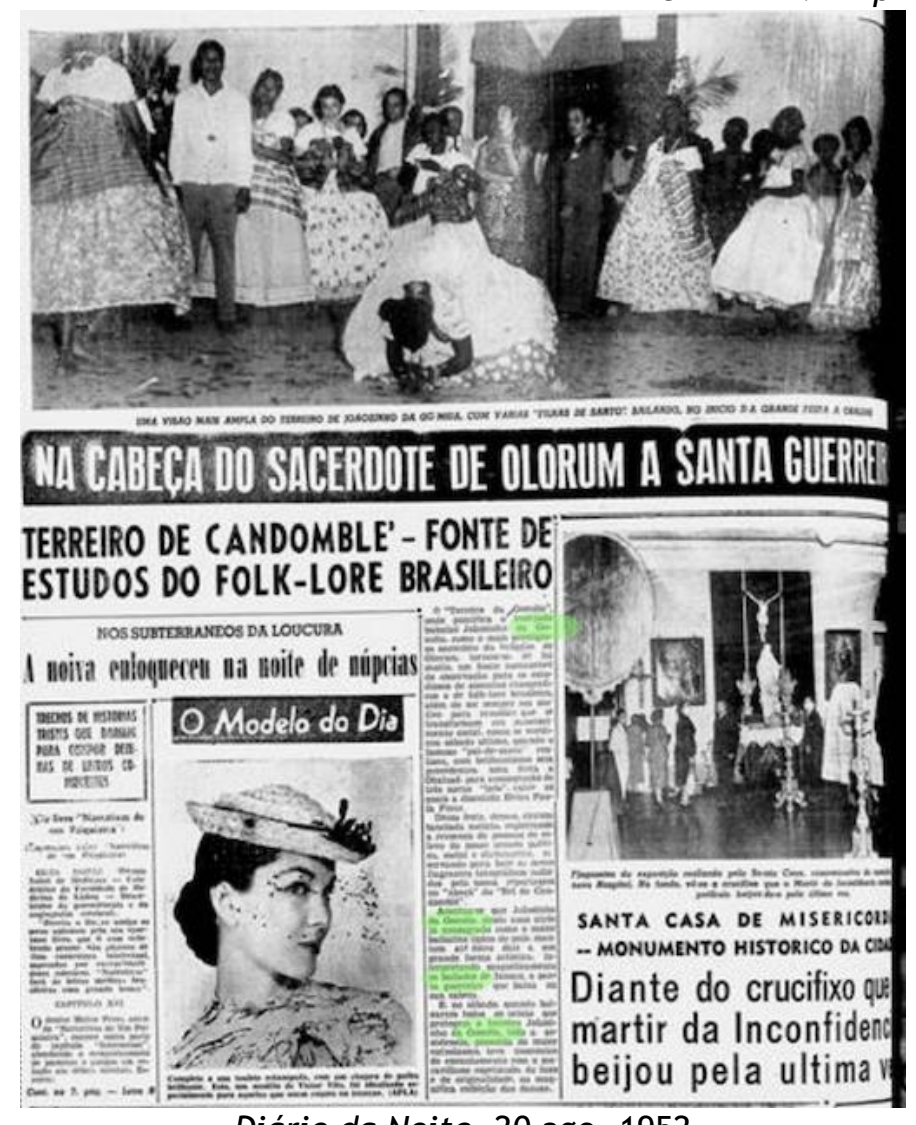

Diário da Noite, 20 ago. 1952

Acentua-se que Joãozinho da Goméia, desde anos atrás já consagrado como o maior bailarino típico do país, mantém até estes dias a sua grande forma artística, interpretando magnificamente os bailados de lansã, a santa guerreira que baixa na sua cabeça. [...] E, no sábado, quando baixaram todos os orixás que protegem o terreiro Joãozinho da Goméia, toda a assistência, possuída do maior entusiasmo, teve momentos de encantamento com o maravilhoso espetáculo de luxo e de originalidade, na magnífica exibição das danças (Trecho da matéria).

João da Gomeia, ao subordinar a ordem midiática, criou um tipo de contradiscurso, de discurso contra-hegemônico, que não deixa de dialogar com as esferas de poder, com os donos das grandes empresas de comunicação hegemônica, com o mainstream do espetáculo, com o mundo da política, com a universidade e seus cânones. Mas é de lá, de dentro da esfera de poder, privilégio e prestígio, que Joãozinho constituirá uma nova esfera pública agora radical, alternativa, que coloca o candomblé e sua gente no topo do 


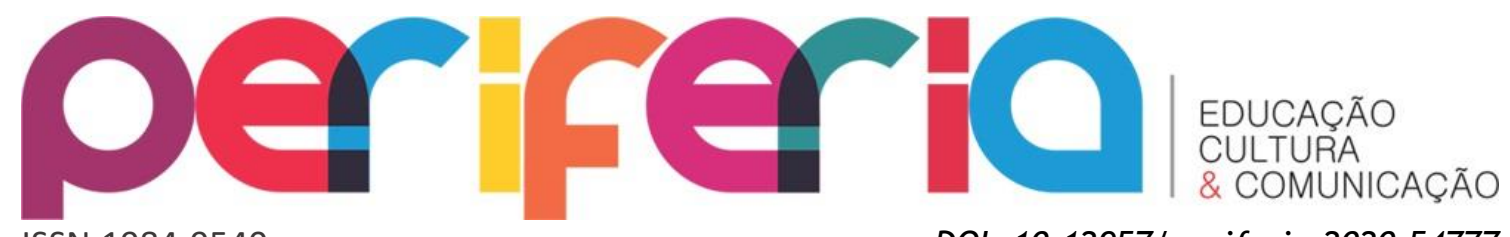

ISSN:1984-9540

DOI: $10.12957 /$ periferia.2020.54777

debate sobre ser negro numa sociedade branca e racista. Nesse sentido, afirmo que João foi importante pelo fato de ter criado uma arena paralela, nos termos de Fraser (1985), ou uma mídia radical alternativa, nos termos de Downing (2002), mesmo quando participava de produções da mídia hegemônica, dialogando, desde dentro com o mainstream e com a sociedade dominante.

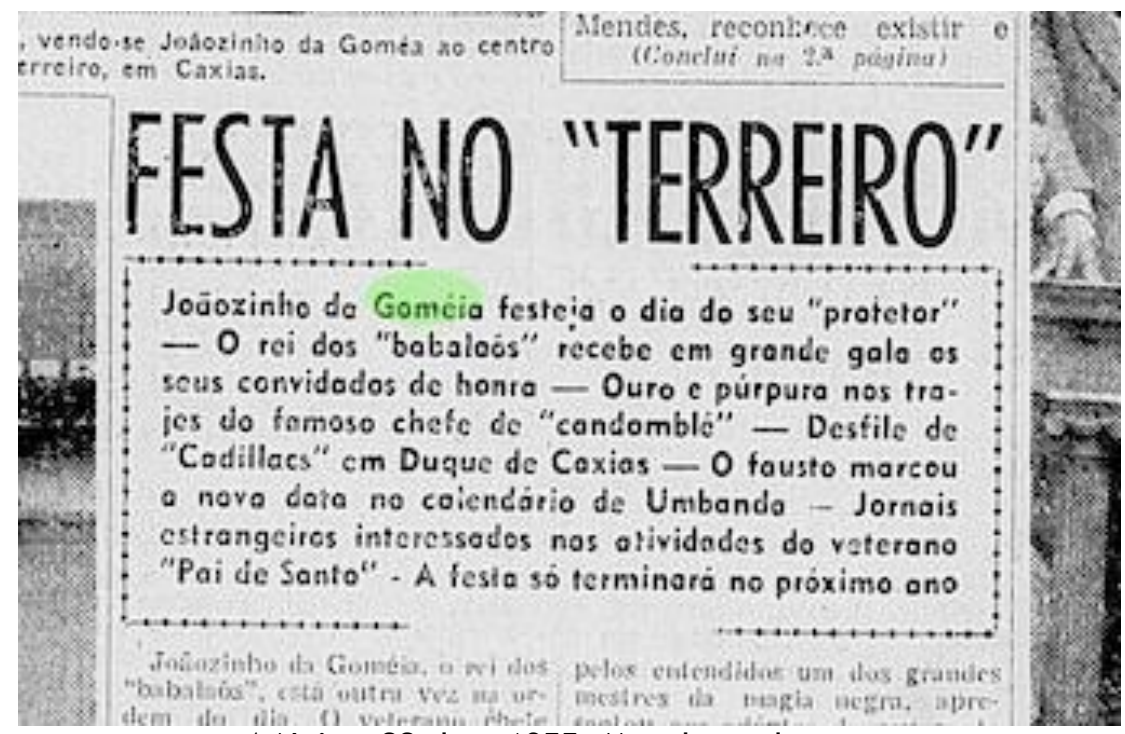

A Noite. 22 dez. 1955. Manchete de capa.

\section{Xalenu Kyambote}

Ainda hoje, é através da mídia - antes, radio, TV, cinema, revista e jornal; agora, mídias digitais e tecnologias de informação e comunicação com acesso à internet - que Joãozinho da Goméia mantém sua fama no Brasil e no mundo. Seus novos admiradores são pessoas jovens, que não viram e nem ouviram falar de João ainda em vida. Já o conheceram fisicamente morto, mesmo que vivo na memória social brasileira. Por isso, afirmo que João é um representante vanguardista, ainda hoje, do universo religioso afro-brasileiro, já que tal fato se deve, única e exclusivamente, à sua participação em mídia, nas muitas mídias, nos muitos veículos de comunicação com as quais conviveu em sua época e dos quais, hoje-, participa. Não à toa, foi como tema central 


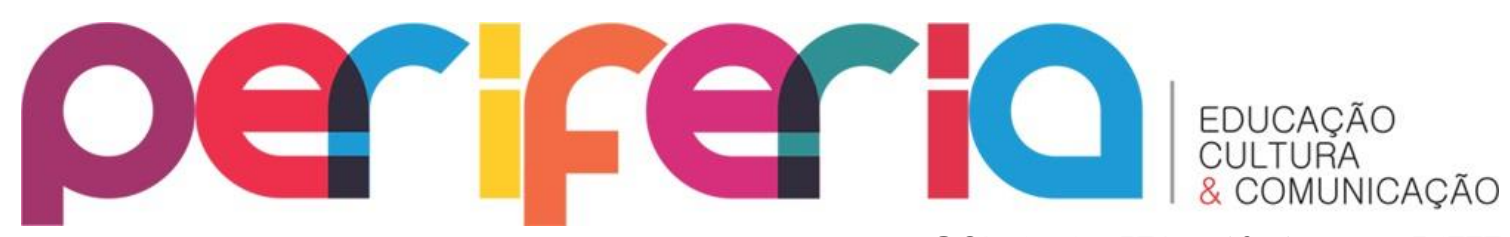

ISSN:1984-9540

DOI: $10.12957 /$ periferia.2020.54777

de um webinário promovido em pleno século $X X I^{23}$, que João me moveu a escrever esse texto.

Em outros termos, a mídia fez de João o que foi e ainda é hoje. Ouso mesmo dizer que a participação em mídia the conferiu mais prestígio do que, certamente, seu conhecimento litúrgico e a iniciação de muitos filhos e filhas. Afirmo isso com certa tranquilidade, já que me apoio nos registros documentais, nas fontes históricas produzidas sobre João, onde encontramos muito mais referências à sua pessoa do que ao seu conhecimento religioso - à exceção dos depoimentos de suas filhas e descendentes de santo; o que, de certo modo, traduz o interesse da mídia sobre o espetacular e seu desinteresse sobre a religião propriamente dita.

João retirou as religiões afro-brasileiras dos noticiários policiais e contribuiu para que representações negativas sobre o candomblé e seus integrantes fossem, de certo modo, amenizadas, tendo importante participação no combate à intolerância e ao racismo religioso. João combateu os muitos clichês e estereótipos que retrataram o candomblé como religião de delinquentes. Desfez as representações construídas sobre o candomblé como religião da barbárie, da selvageria, recorrentemente construídas e reconstruídas, por conta dos seus rituais de sacrifício, possessão e magia. Por isso, é correto afirmar que João falava para fora, para gente de fora do universo religioso, mesmo que também despertasse interesse nas pessoas da religião, no povo de santo, explorando, para tanto, as formas plásticas e a riqueza estética das religiões afro-brasileiras como forma de persuadir os nãoreligiosos.

Ressalta-se, ainda, a importância da sua participação em mídia como expressivo elemento para movimentar o mercado da fé, o mercado de oferta de serviços mágico-religiosos - algo muito corriqueiro a partir da década de 1980, com a compra de emissoras de rádio e TV por igrejas; por isso mesmo, chamadas de igrejas eletrônicas. A diferença desse caso para o caso de João,

${ }^{23}$ Uma série de seminários via web sobre João da Goméia, ocorridos nos meses de agosto e setembro de 2020, sob organização do Museu Vivo do São Bento.

Periferia, v. 12, n. 3, p. 94-128, set./dez. 2020 


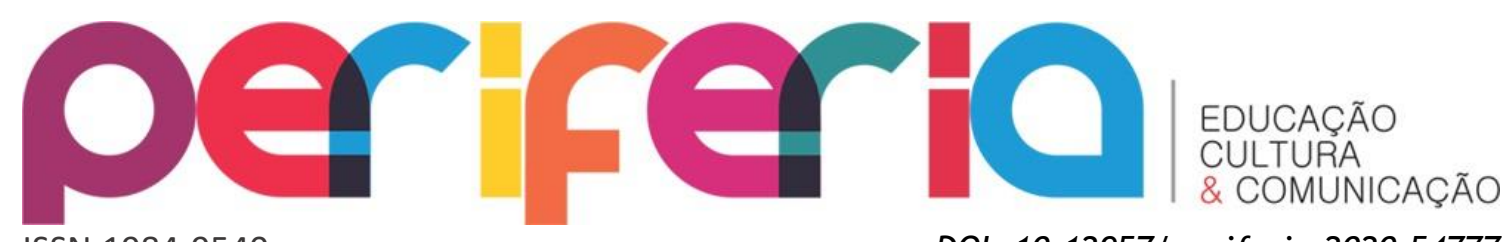

ISSN:1984-9540

DOI: $10.12957 /$ periferia. 2020.54777 é que ele não era dono de emissora. Suas participações e presença em mídia eram participações concedidas, acordadas e, sobretudo, conquistadas, símbolos da sua luta para se fazer visto.

João, repetidamente questionado acerca da pureza do culto por ele realizado, criou uma família de santo que, se foi em algum momento tida como impura e degenerada, após suas recorrentes aparições na mídia, se transformou em sinônimo de tradição, paradigma, cânone disseminador de uma linhagem de santo.

Também vale ressaltar 0 fato de 0 terreiro de João ter sido frequentado por políticos e artistas com reconhecimento nacional e internacional, figuras importantes junto à opinião pública, que contribuiriam para positivar a imagem dos terreiros na sua totalidade (e não somente da Goméia) e, por extensão, para que essas religiões fossem toleradas pela sociedade da época, promovendo, através da presença constante nos veículos de comunicação, o diálogo entre sociedade brasileira mais ampla e religiões afro-brasileiras. Isso permite dizer que João não foi somente um porta-voz das religiões afro-brasileiras, mas, sobretudo, da cultura negra, da cultura afrobrasileira e afro-diaspórica na sua totalidade.

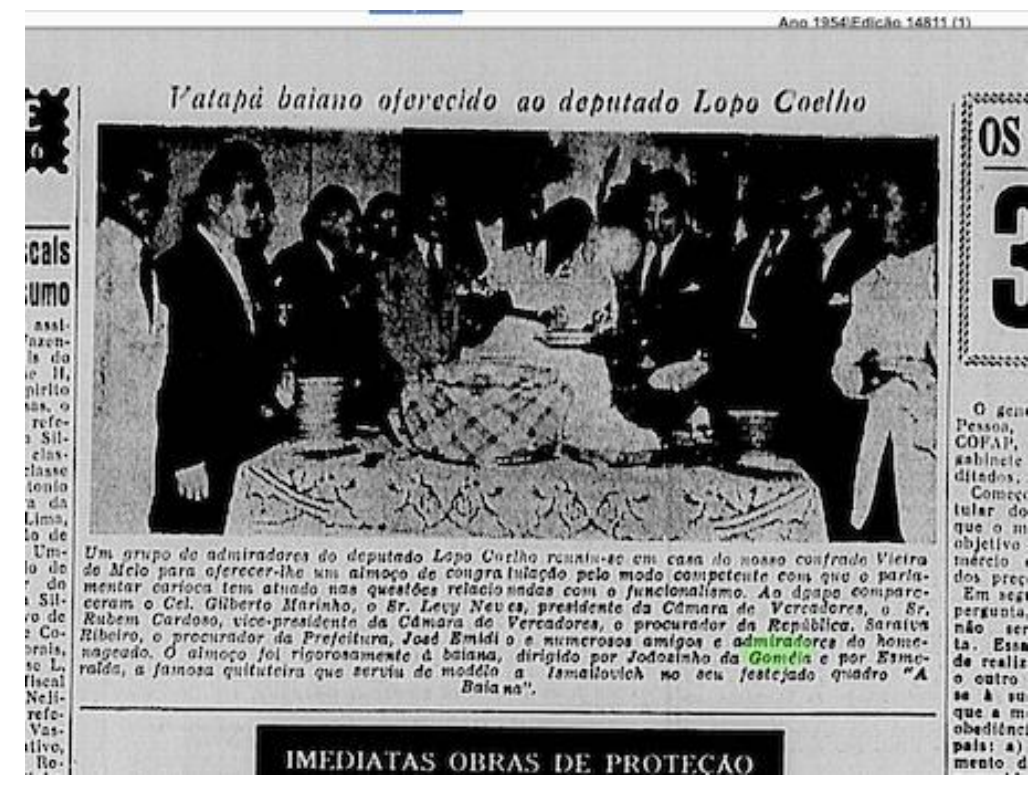

A Noite. 16 set. 1954.

Periferia, v. 12, n. 3, p. 94-128, set./dez. 2020 


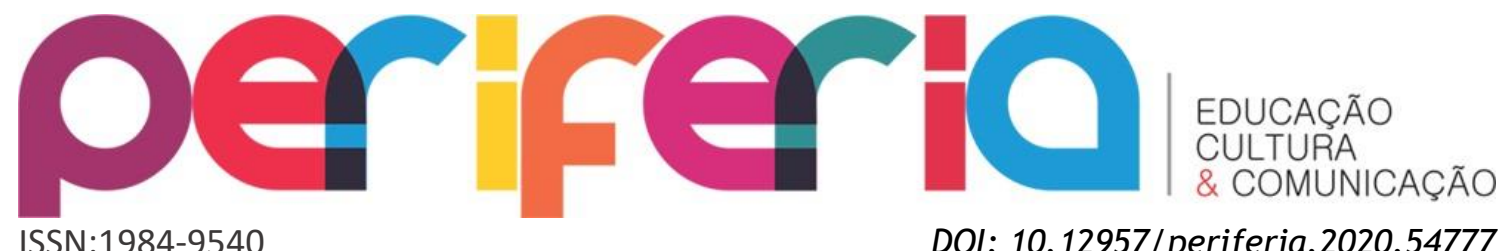

As iniciativas de João também foram importantes por ilustrarem os muitos diálogos, conflitos e rupturas travados entre grupos de integrantes do que aqui tratamos por religiões afro-brasileiras ou candomblé, além dar visibilidade à luta pela legitimidade do candomblé angola, classicamente inferiorizado em relação ao candomblé jeje-nagô.

Ao explorar o caráter cênico e lúdico dessas religiões, João concretiza o trânsito entre terreiro e carnaval, entre a religião e o showbusiness, entre o sagrado e o profano, quando são exaltadas as práticas relacionadas à ludicidade e à festividade que iam de encontro à importante característica da identidade nacional brasileira: a cultura da alegria e da festividade e a prática de modos de religiosidade marcados por manifestações festivas e em diálogo e harmonia com práticas profanas.

0 fato de dançar, de gostar de dançar, num candomblé em que homens não dançavam também merece destaque. João quebra a matrilinearidade da identidade religiosa e abre brechas para a discussão sobre a participação de lideranças homossexuais no universo religioso afro-brasileiro, abrindo as portas para esse tipo de candomblé, em que a figura masculina, de homem gay assumido, em constante diálogo com adereços do universo feminino, assume papel de destaque na constituição do novo masculino que aparece nos terreiros. Por isso, João também é ilustrativo dessas relações entre sagrado e profano, indivíduo e divindade, prazer e fé, que tanto, e ainda hoje, permeiam o modo com que o povo de santo lida com as bipolaridades da vida do dia a dia.

Por fim, é correto afirmar que João do Goméia foi um verdadeiro promoter, um analogic influencer (influenciador analógico) da religião, ao promover o diálogo entre sociedade brasileira e as religiões afro-brasileiras. João deu legitimidade ao candomblé através de atitudes e comportamentos muitas vezes transgressores, mas, sempre muito repercutidos. Essas iniciativas também foram importantes para consolidar as muitas articulações e negociações elaboradas pelos terreiros para dar forma a uma cultura religiosa afro-brasileira e negra, extrapolando os limites do universo religioso e contribuindo para a afirmação da identidade e da cultura de origem africana,

Periferia, v. 12, n. 3, p. 94-128, set./dez. 2020 


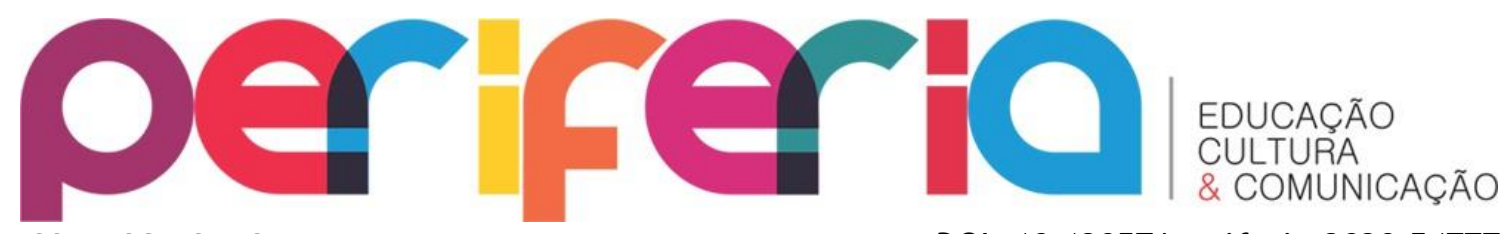

ISSN:1984-9540

DOI: $10.12957 /$ periferia.2020.54777

e até ameríndia, junto à esfera pública - o que faz de João uma pessoa

importante não somente para a religião mas, também, para a valorização da

cultura negra no Brasil e nas Américas.

A gente se sente verdadeiramente honrado de fazer parte dessa história, fazer parte desse legado, de uma pessoa que foi considerada como o Rei do Candomblé, um título que é dado a poucas pessoas, né... Um pai de santo, um ser humano, uma pessoa que estava à frente do seu tempo, que abriu, assim, muitas portas para inovação e uma nova forma de estar também na religião de matriz africana e no candomblé... Quer queira, quer não, na época era dito como uma coisa talvez até ruim, porque ele tava fazendo coisas que não se faziam.... Mas, hoje a gente vê que ele ter feito isso abriu espaço e portas pra muitas outras coisas, pra muitas outras pessoas também fazer, sair de um lugar pra outro, se deslocar e difundir, de uma certa forma, mais e melhor o candomblé, a religião, a fala, esse legado que a gente tem com tanto amor, tanto carinho (Mametu Kamurici, 2019, sic.) 24 .

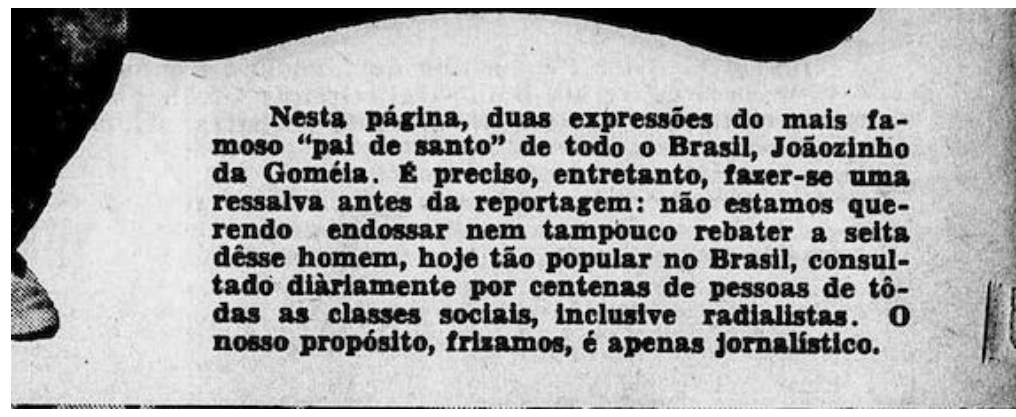

Revista do Rádio. 6 mar. 1954.

${ }^{24}$ Mãe de santo do Terreiro São Jorge Filho da Goméia. Entrevista a Xavier Vantin para o documentário Memórias Afro-Atlânticas. Dir.: Gabriela Barreto. 76 min. Produção: Couraça Criações Culturais, Épuras Laboratório Audiovisual, Salvador, 2019.

Periferia, v. 12, n. 3, p. 94-128, set./dez. 2020 


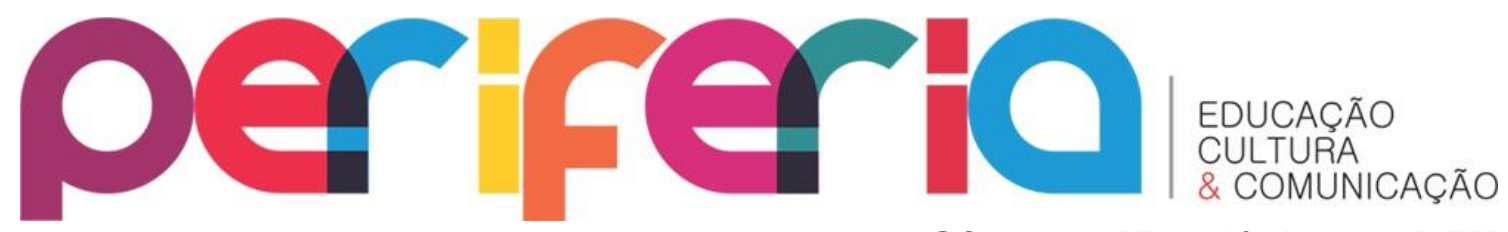

ISSN:1984-9540

DOI: $10.12957 /$ periferia.2020.54777

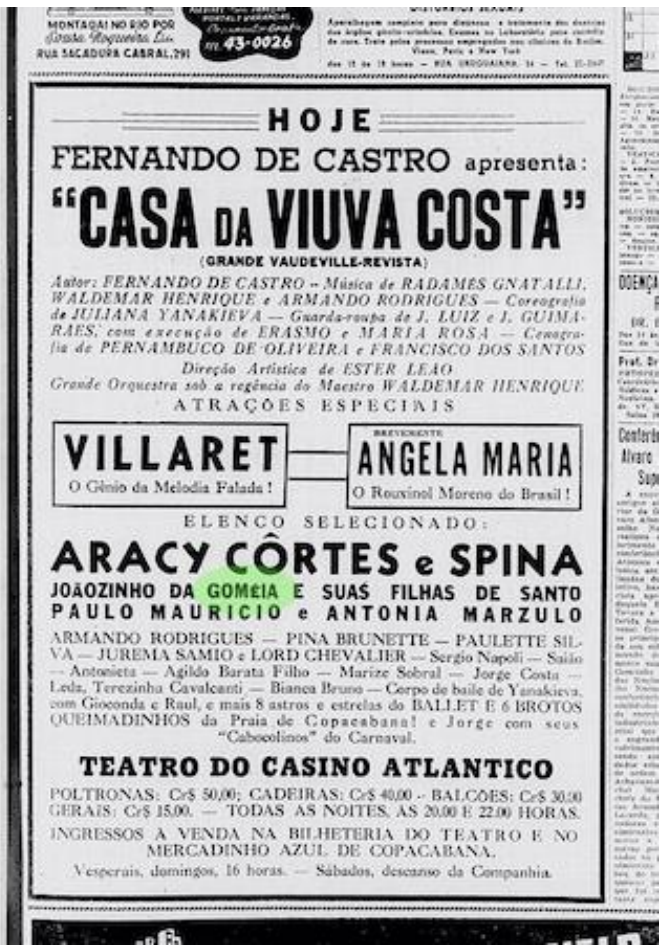

A Noite. 4 dez. 1953.

\section{REFERÊNCIAS}

AMADO, Jorge. Bahia de Todos os Santos: guia de ruas e mistérios. Rio de Janeiro: Record, 1991.

BASTIDE, Roger. As religiões africanas no Brasil: contribuição a uma sociologia das interpetacoes das civilizações

BASTIDE, Roger. Les religions africaines au Brésil: contribution à une sociologie des interpénétrations de civilisation. Paris: Presses Universitaires de France, 1995.

CARNEIRO, Édison. Negros Bantus. Rio de Janeiro: Civilização Brasileira, 1937.

DOWNING, John. Mídia radical: rebeldia nas comunicações e movimentos sociais. São Paulo: Editora Senac, 2002.

FAGUNDES, Ariel. A genealogia oculta dos afro-sambas. Revista Noize. n. 70, Rio de Janeiro, jan-mar. 2017.

FERREIRA, Thiago. João da Goméia: transgressões e identidades de gênero no Candomblé. Disponível em:

<https://bdm.unb.br/bitstream/10483/15310/1/2016_ThiagoAlmeidaFerreira _tcc.pdf >. Acesso em: 25 jul. 2020.

FICHTE, Hubert. Etnopoesia: antropologia poética das religiões afroamericanas. São Paulo: Brasiliense, 1987. 


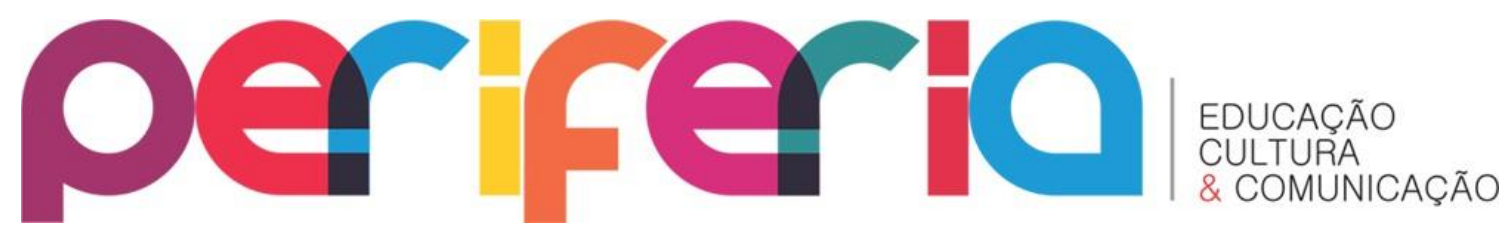

ISSN:1984-9540

DOI: $10.12957 /$ periferia. 2020.54777

FRASER, Nancy. What's Critical about Critical Theory? The case of Habermas and gender. New German Critique, n. 35, 1985.

FREITAS, Ricardo. Candomblé e mídia: breve histórico da tecnologização das religiões afro-brasileiras nos e pelos meios de comunicação. Acervo - Revista do Arquivo Nacional, v. 16, n. 2, p. 63-88, 2003.

FREITAS, Ricardo. Memorial lyá Davina: reflexões sobre o primeiro "museu do candomblé" no Rio de Janeiro. In: GOMES, Edlaine; OLIVEIRA, Paola (Org.). Olhares sobre o Patrimônio Religioso, Rio de Janeiro: Editora Mar de Ideias, 2016.

FREITAS, Ricardo. Candomblé e Internet: ejó, conflito e publicização do privado em mídias digitais. Disponível em:

<https://revistas.uneb.br/index.php/tabuleirodeletras/article/view/7767>. Acesso em: 31 dez. 2019.

FREITAS, Ricardo. Mãe Nitinha e o advérbio revelador. Disponível em: <http://www.observatoriodaimprensa.com.br/educacao-ecidadania/caderno-da-cidadania/mae-nitinha-e-o-adverbio-revelador/> . Acesso em: 26 set. 2020.

GAMA, Elizabeth. Mulato, homossexual e macumbeiro: que rei é este? Trajetória de João da Goméia (1914-1971). 213p. Dissertação, Programa de Pós-Graduação em História, Universidade Federal Fluminense, Niterói, 2012.

Janeiro: Record, 1991.

HABERMAS, Jugen. Mudança estrutural da esfera pública. Rio de Janeiro: Tempo Brasileiro, 1984.

LANDES, Ruth. A cidade das mulheres. 2 ed. Rio de Janeiro: Editora UFRJ, 2002.

LODY, Raul; SILVA, Vagner. Joãozinho da Goméia: o lúdico e o sagrado na exaltação ao candomblé. In: SILVA, Vagner Gonçalves da (Org.). Caminhos da alma: memória afro-brasileira. São Paulo: Selo Negro, 2002.

LUHNING, Angela. Acabe com este santo, Pedrito: mito e realidade da perseguição policial ao candomblé baiano entre 1920 e 1942 . Revista USP, São Paulo, v. 28, p. 194-220, fev. 1996.

MAIA, Rousiley. Dos dilemas da visibilidade midiática para a deliberação pública. Disponível em:

<http://www.compos.org.br/data/biblioteca_937.pdf>. Acesso em: 08 ago. 2020.

MAUSS, Marcel. Sociologia e Antropologia. São Paulo: Cosac e Naify, 2003.

Periferia, v. 12, n. 3, p. 94-128, set./dez. 2020 


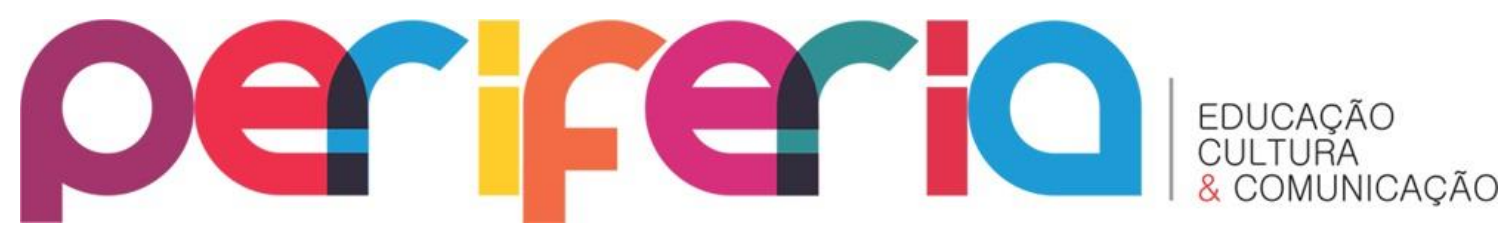

ISSN:1984-9540

DOI: $10.12957 /$ periferia.2020.54777

MENDES, Andrea. Vestidos de realeza: contribuições centro-africanas no candomblé de Joãozinho da Goméia (1937-1967). 181p. Dissertação, Mestrado em História, Instituto de Filosofia e Ciências Humanas, Universidade Estadual de Campinas, Campinas, 2012.

NASCIMENTO, Andréa. De São Caetano à Caxias: um estudo de caso sobre a trajetória do Rei do Candomblé Joãosinho da Goméa. 105p. Monografia, Curso de Licenciatura Plena em História, Faculdade de Formação de Professores, Universidade Estadual do Rio de Janeiro, São Gonçalo, 2003.

NASCIMENTO, Andréa. Reflexões de uma historiadora preta sobre o Rei do candomblé Joãozinho da Goméia. Disponível em:

<https://www.forumgritabaixada.org.br/reflexoes-de-uma-historiadorapreta-sobre-o-rei-do-candomble>. Acesso em: 26 set. 2020.

PIERSON, Donald. Brancos e pretos na Bahia. São Paulo: Editora Nacional, 1971.

RAILLARD, Alice. Conversando com Jorge Amado. Rio de Janeiro: Editor Record, 1990.

SANTOS, Anselmo. Terreiro Mokambo: espaço de aprendizagem e memória do legado banto no Brasil. 133p. Dissertação, Programa de Pós-Graduação em Educação e Contemporaneidade, Universidade do Estado da Bahia, Salvador, 2008.

SERRA, Ordep. Sobre psiquiatria, candomblé e museus. Revista de Ciências Sociais. Salvador, p. 309-323, ago. 2006.

SERRA, Ordep. Sobre psiquiatria, candomblé e museus. Revista de Ciências Sociais do Centro de Estudos e Pesquisas em Humanidades da Universidade Federal da Bahia. v. 19, n. 47. Salvador, 2006.

SIMMEL, Georg. Philosophie de largent. Paris: PUF, 1977.

SILVA, Joselina da. O negro baiano Pai Joãozinho da Goméia: o candomblé de Duque de Caxias na mídia dos anos cinquenta. Revista Magistro. vol. 1, n. 1, p. 38-53, 2010.

SODRÉ, Muniz. A máquina de Narciso: televisão, indivíduo e poder no Brasil. Rio de Janeiro: Editora Achiamé, 1984.

VATIN, Xavier. Memórias Afro-Atlânticas: as gravações de Lorenzo Turner na Bahia (1940-1941). Catálogo, Brasília: Petrobras Cultural, Fundação Palmares, 2017.

WEBER, Max. A ética protestante e o espírito do capitalismo. São Paulo: Pioneira, 1996.

Periferia, v. 12 , n. 3, p. 94-128, set./dez. 2020 